\title{
An evaluation of influential factors on landslide mobility during the 2008 Wenchuan earthquake
}

\section{P. Guo ${ }^{1,2,3}$, M. Hamada ${ }^{2}$, and C. $\mathrm{He}^{1}$}

${ }^{1}$ Key Laboratory of Transportation Tunnel Engineering, Ministry of Education, School of Civil Engineering, Southwest Jiaotong University, Chengdu 610031, China

${ }^{2}$ Department of Civil and Environmental Engineering, Waseda University, 3-4-1Okubo, Shinjuku-ku, Tokyo 169-8555, Japan

${ }^{3}$ Sichuan Railway Investment Group Co.Ltd, Chengdu, 610041, China

Received: 15 June 2013 - Accepted: 6 January 2014 - Published: 21 January 2014

Correspondence to: D. P. Guo (guodeping99@ gmail.com)

Published by Copernicus Publications on behalf of the European Geosciences Union.

\section{Influential factors on landslide mobility during the Wenchuan earthquake \\ D. P. Guo et al.}

\section{Title Page}

\begin{tabular}{|c|c|}
\hline Abstract & Introduction \\
\hline Conclusions & References \\
\hline Tables & Figures \\
\hline $\mathbf{1}$ & \multicolumn{1}{|c|}{$\mid$} \\
\hline & \\
\hline Back & Close \\
\hline Full Screen / Esc
\end{tabular}

Printer-friendly Version 


\section{Abstract}

The 2008 Wenchuan earthquake triggered a huge amount of landslides along the Longmenshan thrust pelt zone in southwest China. It is essential to evaluate the effects of numerous influential factors on landslide mobility, as a result of having seriously 5 endangered the lives and properties along travel path. Hence, the relations between equivalent coefficient of friction $\left(\mu=H_{\max } / L_{\max }\right)$ and other six parameters of 46 landslides, such as three topographical factors, landslide volume, horizontal peak ground acceleration (PHA) and rock type, have been qualitatively analyzed by means of simplified plots and regressions. The quantitative effectiveness of each factor on landslide ility was revealed by multivariable analysis and it was found that slope height, rock type, slope transition angle and landslide volume were more influential than slope angle and seismic acceleration. The statistical significance tests and predictive results both demonstrated that the empirical-statistical model of landslide mobility yielded a satisfactory agreement between observations and predictions, therefore, the presented model could be practically applicable in similar geological conditions as Wenchuan earthquake affected area.

\section{Introduction}

A catastrophic earthquake with $M_{\mathrm{s}} 8.0$ occurs in Wenchuan County, Sichuan Province, in southwestern China on 12 May 2008. The location of the epicenter is $31.0^{\circ}$ north latitude, $103.4^{\circ}$ east longitude, with $14 \mathrm{~km}$ focal depth (China earthquake administration, 2008). It triggers a huge amount of slope failures. The latest result of remote sensing interpretation demonstrates that there are 197481 slope failures triggered in a range of about $110000 \mathrm{~km}^{2}$, and sliding area is totally about $1160 \mathrm{~km}^{2}$ (Xu et al., 2013a, b).

After Wenchuan earthquake, numerous authors have analyzed the relations between
NHESSD

2, 613-647, 2014

\section{Influential factors on landslide mobility \\ during the Wenchuan earthquake \\ D. P. Guo et al.}

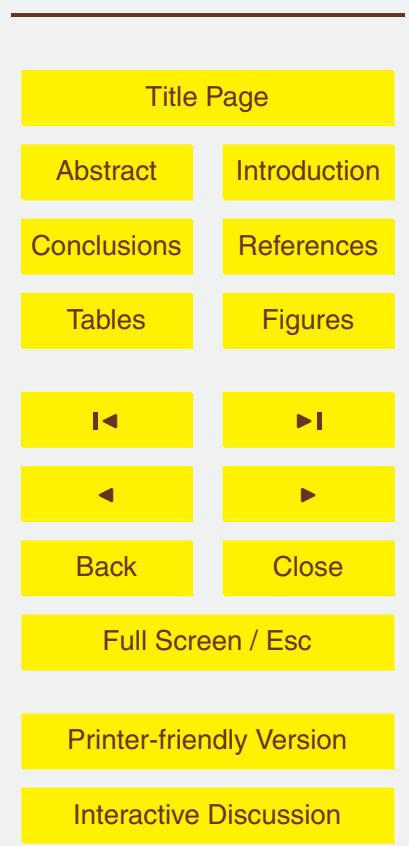


rum et al., 2011; Xu and Xu, 2012; Guo and Hamada, 2013; Xu et al., 2013a, b). However, there are few studies on landslide mobility in Wenchuan earthquake area, expect Qi et al. (2011) who delineated six typical destructive long travel landslides and listed 66 valuable cases, but having just analyzed the relationships between elevation 5 loss and travel distance, as well as sliding area and travel distance. In fact, at least 112 relatively large landslides (volume $>5 \times 10^{4} \mathrm{~m}^{2}$ ) have been triggered during Wenchuan earthquake along seismic source faults (Q. Xu et al., 2009). High mobility landslides have long runout potential, resulting in the debris to block the valley and generating landslide dams to endanger down-stream areas, such as Tangjiashan landslide dam.

During Wenchuan earthquake, 34 landslide dams accompanied with those large landslides (Xie et al., 2008); meanwhile, slope failures are vulnerable to be triggered at no less than 4970 sites based on field investigation by Yin et al. (2009), hence, it is essential to explore landslide mobilization. In order to assess the hazard caused by high mobility landslides, it is necessary to firstly identify what factors have effect on landslide mobility, and how to evaluate the mobilization ability of sliding mass after slope failure.

The discussions for landslide mobility and debris flow mobility have been given, for example, Hungr (1995), Corominas (1996), Okura et al. (2000a, 2000b, 2003), Fannin and Wise (2001), Legeros (2002), Hunter and Fell (2003), Berti and Simoni (2007), Hattanji and Moriwaki (2009, 2011), D'Agostino et al. (2010), Tang et al. (2012) and Pudasaini and Miller (2013). A well-known index expressing landslide mobility is the angle of the line connecting the crest of the landslide source to the distal margin of the deposited mass. This angle was firstly designated as the fahrböschung angle $(\alpha)$ (Heim, 1932; Pudasaini and Hutter, 2007); later, the tangent of this angle was called equivalent coefficient of friction $\left(\mu=\tan \alpha=H_{\max } / L_{\max }\right)$ (Shreve, 1968 and Scheidegger, 1973), and followed by angle of reach (Corominas, 1996), travel distance angle (Hunter and Fell, 2003). A number of authors discussed the relationship between equivalent coefficient of friction $(\mu)$ and sliding volume (Scheidegger, 1973; Hsü, 1975; Corominas, 1996; Legros, 2002; Okura et al., 2000b, 2003), and proposed that the landslide mobility $(1 / \mu)$ shows an increasing trend with the increment of landslide volume. Other
NHESSD

2, 613-647, 2014

\section{Influential factors on landslide mobility during the Wenchuan earthquake \\ D. P. Guo et al.}

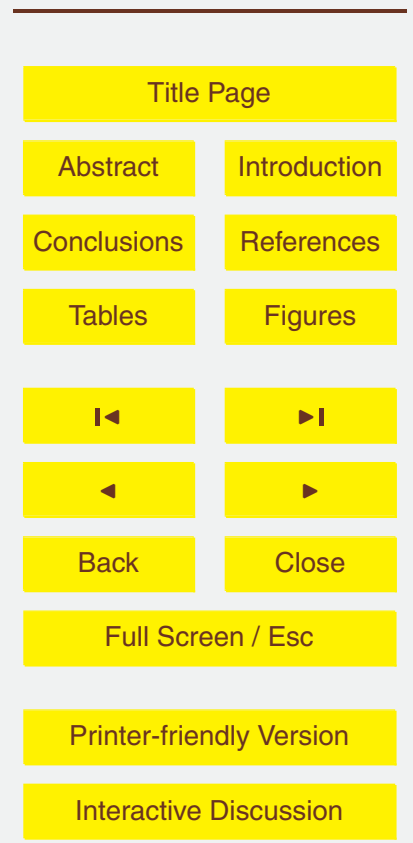


authors, such as Hunter and Fell (2003), Okura et al. (2000a, 2003), Hattanji and Moriwaki $(2009,2011)$, revealed a positive correlation between equivalent coefficient of friction $(\mu)$ and slope angle. Recent statistical analyses ensure the effect of topography on the landslide mobility of constructed and natural slopes (Hunter and Fell, 2003; Hat5 tanji and Moriwaki, 2009; Fan and Qiao, 2010; Pudasaini and Miller, 2013). However, most of these studies are limited to discuss the non-seismically induced landslide; it needs to be explored whether the mobility of earthquake-triggered landslide is consistent with previous studies of non-seismically induced landslides. Furthermore, most of these authors either just qualitatively discussed several influential factors on landslide 10 mobility or just quantitatively analyzed landslide mobility with very few influential factors, such as landslide mobility related to landslide volume or slope angle. However, landslide mobility is simultaneously affected by numerous factors, such as slope angle, slope height, topographic change, landslide volume, rock type, and so on. Therefore, it is necessary to develop a new model to comprehensively consider all of these influences. Hence, this paper is focused on this issue.

Data source is firstly introduced in Sect. 2; the general tendency of equivalent coefficient of friciton related to each influential factor is discussed in Sect. 3. Multivariable regression and backward elimination method are used to explore the effectiveness of each influential factor on equivalent coefficient of friction $\left(\mu=H_{\max } / L_{\max }\right)$ and presents an empirical model to estimate landslide mobility in Sect. 4. Discussions and conclusions are reported in Sect. 5 and Sect. 6, respectively.

\section{Data source}

In this section, we give the definitions of each terminology used in this paper, and briefly introduced data collection methodology.

25 Travel distance, $L_{\max }$, is the horizontal distance between the crest of the sliding source and distal part of debris. Landslide height, $H_{\text {max }}$, is the maximum elevation loss between sliding source and debris. The equivalent coefficient of friction (Shreve, 1968;
NHESSD

2, 613-647, 2014

\section{Influential factors on landslide mobility during the Wenchuan earthquake \\ D. P. Guo et al.}

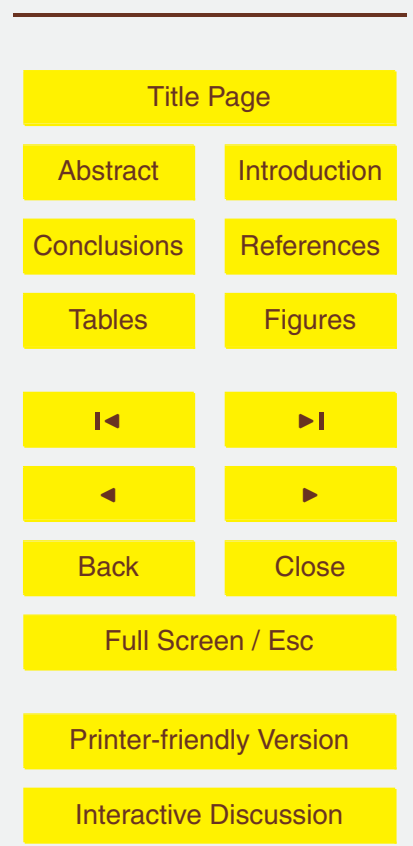


Scheidegger, 1973), $\mu=H_{\max } / L_{\max }$, is equal to the tangent of travel angle $(\alpha)$, namely, the fahrböschung angle (Heim, 1932), angle of reach (Corominas, 1996), or the travel distance angle (Hunter and Fell, 2003). The inverse of this index $(1 / \mu)$ represents the mobilization ability of landslide. The smaller the equivalent coefficient of friction is, the stronger landslide mobility is. The longitudinal profile of a slope is obtained by using topographic map. Based on the density of contour lines, slope is divided into several segments. Contour lines appear relatively sparser, the inclination of corresponding segment will be smaller, and the contour lines become much denser, the corresponding segment has relatively larger slope angle. The interval changing segments of contour lines (marked by ellipse in Fig. 1) along the longitudinal section correspond with the inclination changing segments along a slope. The boundary of contour line interval apparent changing in the topographic map along the slope longitudinal section is regarded as the turning point of different segments of a slope, hence, a slope will be divided into several segments. Slope angle, $\theta$, is the average inclination of the sectional 15 slope within the failed part. Slope height, $h$, is the elevation difference of the sectional slope within the failed part. Topographical effect of slope inclination change between different secitional slopes has strong effect on the impact of sliding mass. Since it will affect the post-impact mobile motion of sliding mass, thereby, slope transition angle, $\beta$, is defined to represent slope inclination changing degree between the upper slope with failed part and lower slope. All of these notations are shown in Fig. 1.

In this paper, collected landslides travelled over a relatively open slope or partly confined by lateral gentle slope, it is means that those landslides were excluded, which was obstructed by river, valley and relatively large infrastructures or confined by lateral steep slope or travelled over a large deflection path. Totally, 46 landslides are selected based on remote sensing interpretation, field investigation and detail descriptions of published papers and books. The distribution of these 46 landslides is illustrated in Fig. 2. Landslide source volume ranges within $4.5 \times 10^{4}-2.75 \times 10^{7} \mathrm{~m}^{3}$, and horizontal travel distance is between 347 and $4170 \mathrm{~m}$.
NHESSD

2, 613-647, 2014

\section{Influential factors on landslide mobility during the Wenchuan earthquake \\ D. P. Guo et al.}

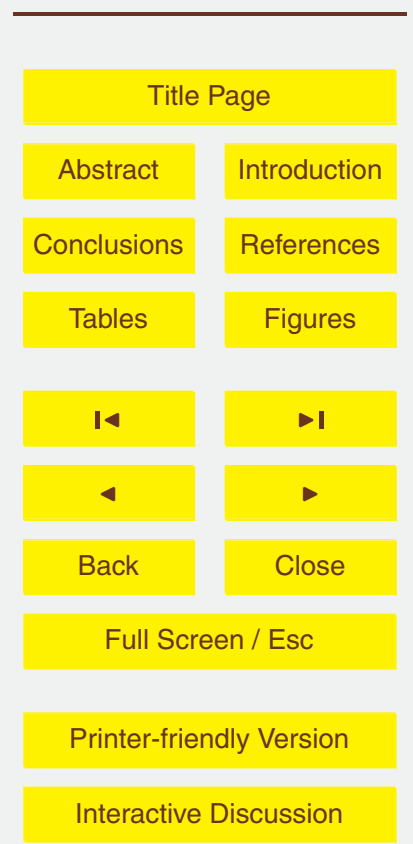


The sliding source area of landslide is calculated by ArcGIS software based on geological map. Landslide source volume is estimated from sliding area multiplied by average collapse depth of sliding body. The average collapse depth is obtained from typical longitudinal profile of slope, as shown in Fig. 3. According to the strength and 5 the degree of weathering, rock materials are classified into two types, such as hard rock and soft rock, which are further divided into two subclasses, respectively, as listed in Table 1. Equation (1) is used to calculate horizontal peak ground acceleration (PHA) of each landslide, which considers hanging-foot wall effect (Guo and Hamada, 2013).

$\ln \mathrm{PHA}=a_{1} \ln \left(D_{\text {rup }}+a_{2}\right)+a_{3} D_{\text {rup }}+a_{4}$

10 where PHA refers to horizontal peak ground acceleration, in $\mathrm{cms}^{-2} ; D_{\text {rup }}$ represents nearest distance from site to Yingxiu-Beichuan surface fault rupture $(\mathrm{km})$, which is located by using USGS simulation result (Chen and Hayes, 2008); $a_{1}, a_{2}, a_{3}, a_{4}$ are the regression coefficients, listed in Table 2 , in which $R^{2}$ stands for coefficient of determination.

\section{Qualitative analysis of influential factors on landslide mobility}

\subsection{The effects of topographical factors}

Topoghraphical factors play an improtant role in landslide mobility (Okura et al., 2003). In the following, three parameters will be discussed, such as slope ange $(\theta)$, slope transition angle $(\beta)$ and slope height $(h)$.

Statistical result, shown in Fig. 4, suggests that the equivalent coefficient of friction of landslides induced by Wenchuan earthquake has a positive, but weak, correlation to the tangent of slope angle. It implies that landslide mobility $(1 / \mu)$ decreases with the increment of slope angle $(\theta)$, which is attributable to the positive correlation between internal friction coefficient and slope angle (Okura et al., 2003). That is to say, kinetic

\section{NHESSD}

2, 613-647, 2014

\section{Influential factors on landslide mobility during the Wenchuan earthquake \\ D. P. Guo et al.}

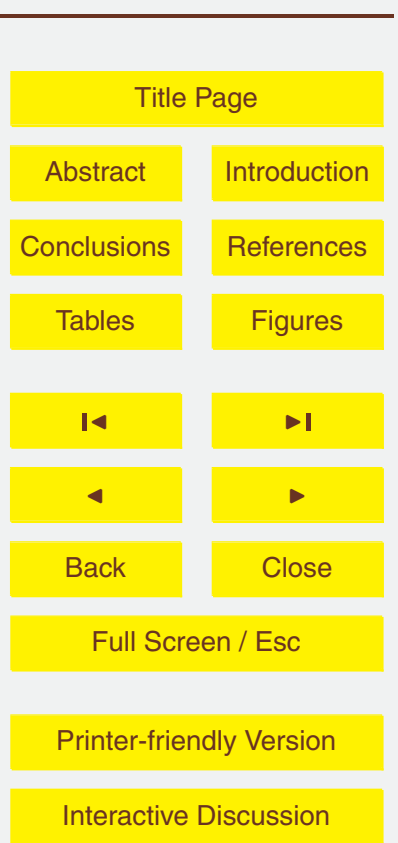


energy consumed by internal friction has positive correlation to slope angle; meanwhile, the steeper the slope is, the faster the velocity of sliding mass is, the higher the consumption of kinetic energy due to impact at the foot of upper slope. Therefore, the likelihood of high mobilization landslide was relatively low to ocurr on the steep 5 or very steep slope. This general tendency related to the tangent of slope angle of earthquake-induced landslides is consistent with previous studies on non-seismically induced landslides (Okura et al., 2003; Hunter and Fell, 2003; Hattanji and Moriwaki, 2009, 2011).

The changing degree of slope inclination is represnted by slope transition angle $(\beta)$. 10 The relationship between the equivalent coefficent of friction and the sine of slope transition angle is illustrated in Fig. 5, which suggests that there is no statistical correlation and tendency. However, the histogram in Fig. 6 illustrates that $45 \%$ landslides concentrates in the range of $160-170^{\circ}$ slope transition angle. It may be explained by that when slope transition angle is relatively small, a large amount of kinetic energy is dissipated by serious impact due to the large inclination change between upper slope and lower slope. With the increment of slope transition angle, energy consumed by impact at slope foot decreases, and the falling mass is crushed and resultes in the transform of mobile motion from sliding to rolling or flowing, then residual energy drives rolling or flowing mass to travel relatively longer. Howerver, when slope transition angle is large enough to ignore the topographical slope change, the motion of failure mass is highly probable to slide as a relatively intact quasi-rigid body, then kenetic energy will be consumed by sliding friction. Because sliding motion generally consumes more kinetic energy than rolling or flowing motion, then sliding mass will be decelerated faster than rolling or flowing mass. Therefore, landslides within the group of $170-180^{\circ}$ slope transition angle becomes fewer than those in $160-170^{\circ}$ k

The relation between the equivalent coefficent of friction and slope height is shown in Fig. 7. Although statistical correlation is very weak, the general tendency suggests that the equivalent coefficent of friction increases with the increment of slope height. It may be explained by that slope height implies the potential energy of failed mass
NHESSD

2, 613-647, 2014

\section{Influential factors on landslide mobility during the Wenchuan earthquake \\ D. P. Guo et al.}

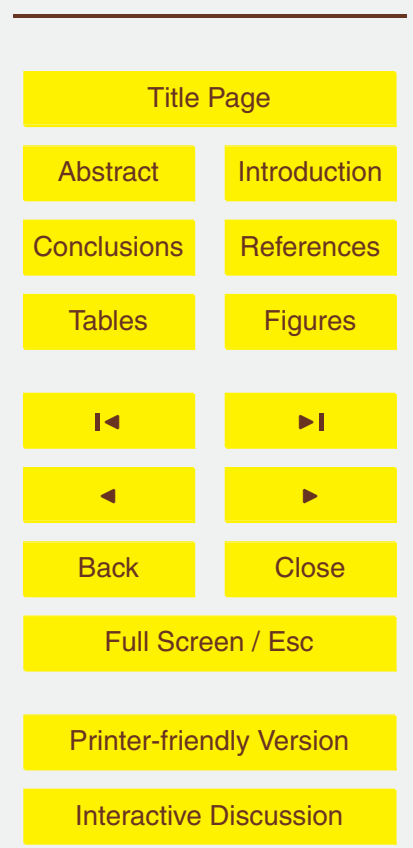


and governs the available space to accelerate the failed mass. The higher slope height is, the larger velocity is, then larger velocity will result in a larger amount of kinetic energy loss due to impact, namely, the higher slope is, the larger kenetic energy will be dissipated. When larger kenetic energy is consumed, landslide mobility $(1 / \mu)$ would 5 be lower, hence, the equivalent coefficent of friction $(\mu)$ has a positive correlation with slope height.

\subsection{The effect of seismic acceleration}

In order to explore the trend between landsldie mobility and seismic ground motion, the formulae, as Eq. (1), are used to estimate horizontal peak ground acceleration of each 10 landslide. The result is illustrated in Fig. 8, which suggests that the equivalent coefficent of friction has no correlation to peak ground acceleration. It implies that seismic acceleration has little effect on landslide movement. Backward analyzing the scale of 46 landslides, it is found that the volume of these 46 landslides is in the range of $4.5 \times 10^{4}-$ $2.75 \times 10^{7} \mathrm{~m}^{3}, 65 \%$ landslide volumes are larger than $10^{6} \mathrm{~m}^{3}$, and 39 volumes out of the 15 total are larger than $5.0 \times 10^{5} \mathrm{~m}^{3}$. From the viewpoint of earthquake energy Kokusho et al. (2009) proposed that the potential energy of very large landslide would be big enough to ignore the effectiveness of earthquake energy on landslide movement; the effect of earthquake was playing a trigger role rather than making landslide have high mobility and driving sliding mass to travel long away. Therefore, the result of our field investigation gives an evidence to the statement of Kokushao et al. (2009).

\subsection{The effect of rock type}

Rock type is another influential factor on landslide mobility. However, it is changeable along travel path due to wide zone affected by sliding debris, therefore, discussed lithology is limited within the sliding source range for the typical rock type. According to rock strength and weathered degree, rock materials are classified into two types and four sub-classes, as shown in Table 1. The statistical result is illustrated in Fig. 9. It sug-
NHESSD

2, 613-647, 2014

\section{Influential factors on landslide mobility during the Wenchuan earthquake \\ D. P. Guo et al.}

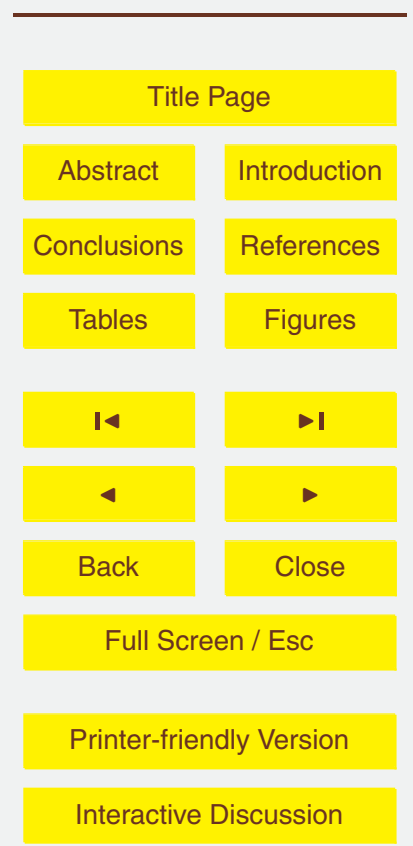


gests that equivalent coefficients of friction of landslides consisting of hard rock are in a smaller range than those of soft rock, which indicates that landslides consisting of hard rock generally have higher mobility (smaller $\mu$ ) than those consisting of soft rock. The reason is inferred that the sliding or rolling friction coefficient between soft rock and 5 travel path is larger than that of hard rock; besides, it might be caused by the difference of mobile mechanics. The behavior of soft rock is possible to be viscoplasticity, while the behavior of hard rock is probable to be plasticity; hence, soft rock consumes more kinetic energy than hard rock along travel path, resulting in equivalent coefficients of friction of soft rock landslides distribute within a larger range.

\subsection{The effect of landslide $\wedge$ volume}

There are lots of previous studies on the relationship between landslide mobility and sliding volume induced by non-seismic causes (Scheidegger, 1973; Hsü, 1975; Corominas, 1996; Legros, 2002; Okura et al., 2003; Pudasaini and Miller, 2013). Scheidegger (1973) stated a negative linear correlation between landslide volume and equiv15 alent coefficient of friction in log-log scale when volume beyond $10^{5} \mathrm{~m}^{3}$; while Hsü (1975) stated the threshold value of this negative linear correlation is $5 \times 10^{5} \mathrm{~m}^{3}$. However, there are few studies on the relationship between landslide volume and its mobility induced by earthquake. Based on 46 landslides triggerred by the 2008 Wenchuan earthquake, there is no significantly emprical formula. Nevertheless, Fig. 10 illustrates a general tendency in log-log scale graph after excluding four landslides smaller than $2.55 \times 10^{5} \mathrm{~m}^{3}$. It suggests that the equivalent coefficient of friction and sliding source volume has negative correlation, which is consistent with previous researches on landslides induced by non-seismic causes.

\section{NHESSD}

2, 613-647, 2014

\section{Influential factors on landslide mobility during the Wenchuan earthquake \\ D. P. Guo et al.}

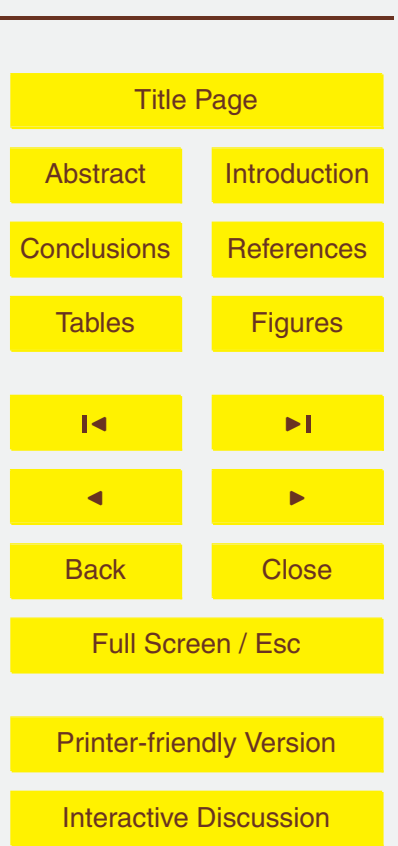




\section{Statistical model of landslide mobility}

Based on one by one analysis of single factor on the equivalent coefficient of friction related to six influential factors, the results suggest that each influential factor has more or less effect on landslide mobility, but the statistical correlations between the equiva5 lent coefficient of friction and each influential factor are very weak, even no correlation, it implies that if only considering one influential factor, it is impossible to obtain a reliable regression model to estimate landslide mobility based on these 46 landslides triggered in Wenchuan earthquake area; it also implies that landslide mobility is not affected by one main factor but simultaneously affected by numerous factors. As a result of numerous influences on landslide mobility, in order to clarify which factor/factors is/are predominant, multivariable analysis will be used to quantitatively explore the effectiveness of each factor on the equivalent coefficient of friction in this section.

\subsection{Statistical model development}

The correlation coefficients among six influential factors are listed in Table 3, it suggests 15 $\log h$ has medium correlation to $\log V$ and $\sin \beta$. Because landslide mobility $(1 / \mu)$ is simultaneously affected by numerous factors, the equivalent coefficient of friction is supposed to be linearly correlated to all of these influential factors and obeys the model shown in Table 4. Multiple linear regression is implemented and backward elimination approach is applied to obtain optimization model in the aid of $F$ tests and $t$ tests. The regression procedures and results are listed in Table 4.

In Table $4, \mu=H_{\max } / L_{\max }$ refers to the equivalent coefficient of friction. $h$ represents slope height $(\mathrm{m})$. RT refers to rock type, it is qualitatively considered and $4,3,2$, and 1 are respectively assigned to RT1, RT2, RT3 and RT4. $\beta$ represents slope transition angle $\left({ }^{\circ}\right) . V$ represents landslide volume $\left(\mathrm{m}^{3}\right) . \theta$ denotes slope angle $\left({ }^{\circ}\right)$. PHA refers to horizontal peak ground acceleration $\left(\mathrm{ms}^{-2}\right)$, estimated by Eq. (1). The basis of logarithm is 10 . Multiple $R$ means multiple correlation coefficient, which represents

NHESSD

$2,613-647,2014$

\section{Influential factors on landslide mobility during the Wenchuan earthquake \\ D. P. Guo et al.}

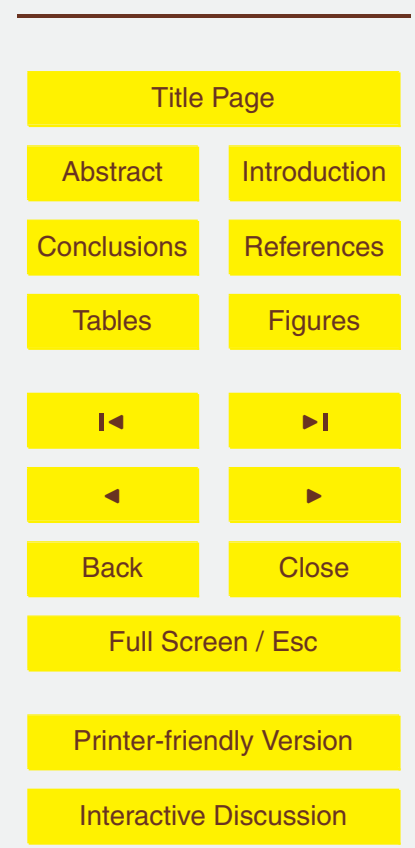


the correlated level between dependent variable and independent variables. Adjusted $R^{2}$ represents adjusted coefficient of multiple determination, namely, adjusted squared multiple correlation, which reveals the goodness of fit, ranging from 0 for no correlation to 1 for a perfect correlation. $F$-stat denotes regressive $F$ value, $F_{0.05}$ denotes $F$ test 5 threshold value with $95 \%$ significance level, if $F$-stat is bigger than $F_{0.05}$, it suggests overall regression of the model satisfies statistical significance level. $t$-stat denotes regressive $t$ value of each regression coefficient, $t_{0.05}$ denotes $t$ test threshold value with $95 \%$ significance level, if $t$-stat is larger than $t_{0.05}$, it suggests corresponding regression coefficient, $b_{i}$, satisfies significance level of regression coefficient. However, not 10 all regression coefficients are significant during regression procedures, therefore, the variable with smallest absolute $t$-stat value (bold digit in the Table 4) is eliminated and then re-regressed, step by step until overall regression of the model and all regressive coefficients both satisfy significance level. These procedures are named as backward elimination regression. Because the units of independent variables affect regression coefficient, $b_{i}$, therefore, standardized regression coefficient, $b_{i}^{\prime}$, is applied to exclude the effect of unit dimension, so as to have insight into the effectiveness of each independent variable on dependent variable.

Compared three models in Table 4, $F$ tests suggest that all of these hypothetical models have statistical significance and satisfy linear assumption. Based on those absolute values of standardized regression coefficients in the 4 variables' model and the procedures, they both suggest that slope height, rock type, slope transition angle

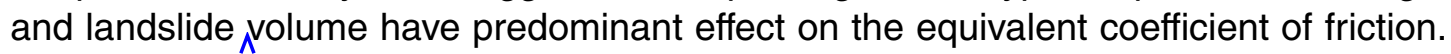
Slope angle and seismic acceleration have relatively weaker influence. Furthermore, the model with 4 variables satisfies not only overall statistical significance but also the significance of each regression coefficient. Hence, the empirical optimization model for the estimation of equivalent coefficient of friction is as follows:

$\mu=H_{\max } / L_{\max }=0.564 \log h-0.077 \mathrm{RT}-0.376 \sin \beta-0.096 \log V$

\section{NHESSD}

2, 613-647, 2014

\section{Influential factors on landslide mobility during the Wenchuan earthquake \\ D. P. Guo et al.}

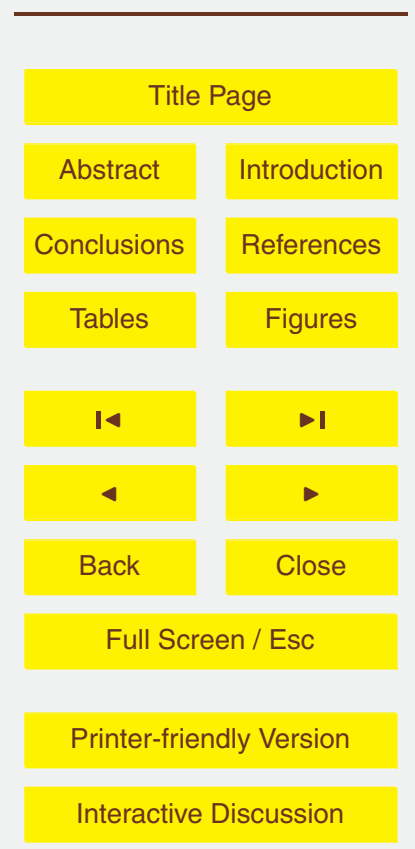


The predicted equivalent coefficients of friction by Eq. (2) and observed values are compared in Fig. 11, which suggests this empirical model is effective for most of landslides in this dataset. Therefore, this model might be useful to predict landslide mobility in Wenchuan earthquake affected area and similar geological and geomorphological 5 areas.

\subsection{Comparison with previous models}

There are many previous studies on landslide mobility, and several prediction models are worldwide established. They are summarized in Table 5. Making use of these four previous models to estimate equivalent coefficients of friction of these 46 landslides 10 triggered by Wenchuan earthquake, the results are shown in Fig. 12, which suggests that the model proposed by Corominas (1996), Hunter and Fell (2003) yield the lowest agreement with observed values, the average estimation errors of these two models are $43.73 \%$ and $45.97 \%$, respectively. The reason why these two previous models are not suitable in Wenchuan earthquake affected area is inferred. For Corominas mode ${ }_{k}$ 15 it was developed from a dataset including $35 \%$ debris flows ( 71 debris flows out of 204 landslides). As a result of debris flow appears a special mobile mechanics due to relatively higher water content of failed mass, this type of landslide is very different from other types of landslide, such as, rotational landslide, translational landslide, block slide, and so on. The high water content of sliding mass generally makes it have higher 20 mobility (namely, smaller $\mu$ ). Since the model of Corominas (1996) partly reflects the characteristics of debris flow, therefore, the predictive equivalent coefficients of friction by Corominas model are generally smaller than the observed in Wenchuan earthquake induced landslides, as shown in Fig. 12. For the model proposed by Hunter and Fell (2003), its lower reliability might be attributable to the amount limitation of data source, 25 where only 11 landslides were used. Compared the model presented in this paper with the models of Scheidegger (1973) and Legros (2000), the results suggest that the average estimation error of Eq. (2) is $10 \%$ lower than these two models. In general,

\section{NHESSD}

2, 613-647, 2014

\section{Influential factors on landslide mobility during the Wenchuan earthquake \\ D. P. Guo et al.}

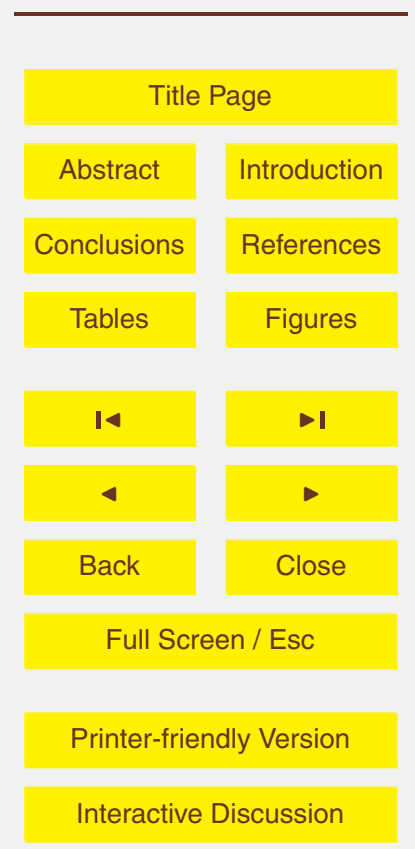


the validity of Eq. (2) is much higher than that of previous 4 models in Wenchuan earthquake affected area.

\section{Discussions}

The disaster caused by high mobility landslide is severe, such as Donghekou land5 slide travelled about $2.6 \mathrm{~km}$ and buried four villages and more than 780 lives (Qi et al., 2011), while landslide mobility is affected by numerous factors, such as topographical factors, the degree of path confinement, geomechanical properties of rock (soil), mobile mechanics, and so on. Therefore, how to express and estimate landslide mobility is a very complicate issue. Corominas (1996) pointed out that travel distance $\left(L_{\max }\right)$ was 10 not an appropriate indicator of landslide mobility, because high falls result in long horizontal reaches, but longer horiztonal distances do not necessarily correspond to lower travle angle $(\alpha)$ (higher mobility). Hence, this paper used the ratio of $H_{\max }$ to $L_{\max }$ as an index of landslide mobility, which was termed by Shreve (1968) and Scheidegger (1973) as equivalent coefficient of friction. The reasons why we applied the maximum 15 horizontal travel distance, instead of the travel distance of gravity center, are as follows: firstly, maximum horizontal travel distance $\left(L_{\max }\right)$ is more applicable to estimate the farthest reach and forecast the potentially endangered area. Secondly, how to estimate the gravity center of sliding mass is so difficult that it is highly possible to result in deviation, thereby affecting the reliability of prediciton model.

The effects of six influential factors on the equivalent coefficient of friction are explored by qualitative and quantitative analysis according to 46 landslides triggered by the 2008 Wenchuan earthquake. However, the results suggest that the general tendencies of each influential factor related to the equivalent coefficent of friciton are very weak, even no correlation. It implies that the equivalent coefficent of friction is controlled by several factors simultaneously, instead of one main factor. It also might be caused by the discretization of data, because some data are collected from field investigation and remote sensing interpretation, while some data are from the detail descriptions of

\section{NHESSD}

2, 613-647, 2014

\section{Influential factors on landslide mobility during the Wenchuan earthquake \\ D. P. Guo et al.}

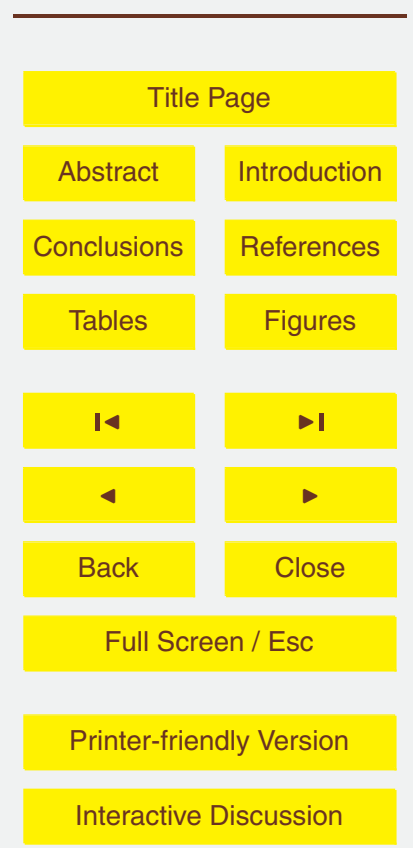


published papers and books. The collection criteria are that: excluding landslides obstructed by river, valley and relatively large infrastructures; excluding travel path confined by lateral steep slope; excluding travel path with large deflection. As a result of these strict criteria, the dataset includes limited amount of landslide. Another problem 5 is that how to judge the degree of path confinement during the investigation. It is so difficult as to be more or less subjective and depend on personal experience. Although it is hard to give a clear definition about the confinement degree of travel path, the multivariable regressive method, shown in Table 4, gives a reasonable approach to obtain an empirical prediction model for estimating landslide mobility $(1 / \mu)$. The validity 10 of proposed empirical model is verified by comparing prediction and observation, as shown in Fig. 11. However, the plot of prediction vs. observation is a litter $x_{\Lambda}$ scattering, not being close to $1: 1$ solid line. It is inferred that the discretization of data source and statistical error caused the prediction deviation; meanwhile, different types of landslide also contribute to the prediction deviation, because the dataset includes rock (or soil) slide, rock avalanche and debris avalanche. The proposed Eq. (2) here is a general model to express the landslide mobility of above mentioned different types of landslide. 46 landslides are not further classified into several groups based on landslide type; if classified, the regression model of each type of landslide would be uncertainty. Meanwhile, note that, the data of sliding source volume used here ranges within $4.5 \times 10^{4}-$ $2.75 \times 10^{7} \mathrm{~m}^{3}$, and horizontal travel distance ranges within $347-4170 \mathrm{~m}$. Due to the difficulty of regional field investigation in Wenchuan earthquake affected area, ground water and geological structures have not been considered in the model of Eq. (2), but these two factors are important for landslide mobile mechanics. Further study is needed to improve this model to consider more influential factors on landslide mobility, and it is necessary to further verify its applicability in much larger volume range and under different geological conditions.

\section{NHESSD}

2, 613-647, 2014

\section{Influential factors on landslide mobility during the Wenchuan earthquake \\ D. P. Guo et al.}

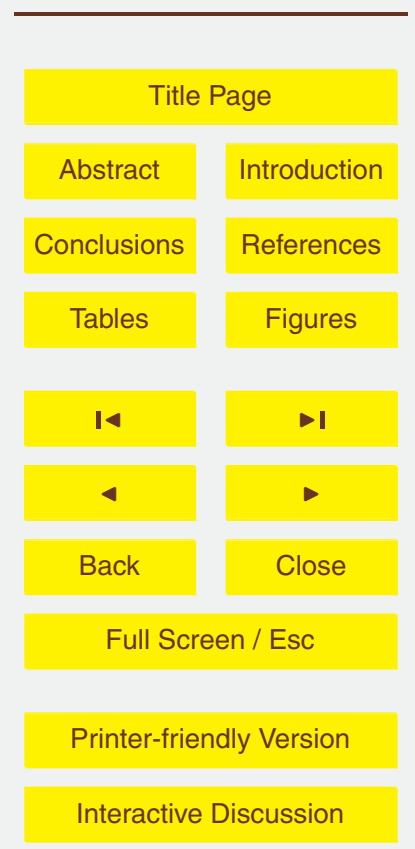




\section{Conclusions}

In this study, the authors collected 46 landslides to discuss landslide mobility with respect to six influential factors, such as slope angle $(\theta)$, slope transition angle $(\beta)$, slope height $(h)$, rock type $(\mathrm{RT})$, landslide ${ }_{\Lambda}$ olume $(V)$, horizontal peak ground acceleration 5 (PHA). The authors applied equivalent coefficent of friciton $\left(\mu=H_{\max } / L_{\max }\right.$; Shreve, 1968; Scheidegger, 1973) as an indicator of mobilization ability of failed mass, namely, landslide mobility $(1 / \mu)$. Based on the qualitative and quantitative analysis, some findings are obtained as follows:

1. Equivalent coefficent of friciton has weakly positive correlation with slope angle and slope height, and no correlation with horizontal peak ground acceleration; landslides consisting of hard rock appeares higher mobility than those consisting of soft rock.

2. Equivalent coefficent of friciton generally has negative correlation to the landslide volume, this trend is similar to previous studies on non-seismically induced landslides.

3. Multivariable analysis in Table 4 reveals that slope height, rock type, slope transi-

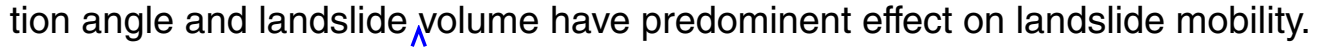

4. An emprical-statistical model, as Eq. (2), is proposed to predict the equivalent coefficent of friciton in similar geological and geomorphological conditions as Wenchuan earthuqake affected area.

Acknowledgements. China Scholarship Council is deeply appreciated to support the first author to study in Waseda University. The authors acknowledge the financial support provided by the National Basic Research Program of China (no. 2010CB732105), the Joint Fund of National Natural Science Foundation of China and High-speed Railway (no. U1134208), National

25 Science and Technology Support Program (no. 2012BAG05B03). Sincere appreciation is to anonymous researchers for timely in-suit investigating after the 2008 Wenchuan earthquake. The authors are greatly grateful to reviewers for their thoughtful comments.

\section{7}

NHESSD

2, 613-647, 2014

\section{Influential factors on landslide mobility during the Wenchuan earthquake \\ D. P. Guo et al.}

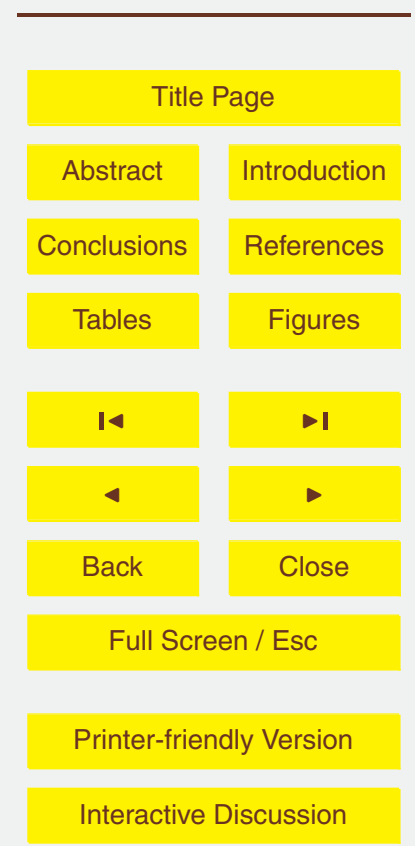




\section{References}

Berti, M. and Simoni, A.: Prediction of debris flow inundation areas using empirical mobility relationships, Geomorphology, 90, 144-161, 2007.

Chang, S. B., Zhang, S. M. et al.: Manual of Engineering Geology, 4th edn., China Architecture 5 \& Building Press, 17-18, Beijing, 2006 (in Chinese).

Chen, J. and Hayes, G.: Finite fault model-preliminary result of the 12 May $2008 \mathrm{Mw} 7.9$ eastern Sichuan, China earthquake, available at: http://earthquake.usgs.gov/earthquakes/ eqinthenews/2008/us2008ryan/finite_fault.php, 2008.

Chigira, M., Wu, X. Y., Inokuchi, T., and Wang, G. H.: Landslides induced by the 2008 Wenchuan earthquake, Sichuan, China, Geomorphology, 118, 225-238, 2010.

China earthquake administration (CAE): Information from website, available at: http://www.cea.gov.cn/manage/html/8a8587881632fa5c0116674a018300cf/_content/ 09_02/02/1233562368699.html, 2008.

Corominas, J.: The angle of reach as a mobility index for small and large landslides, Can. Geotech. J., 33, 260-271, 1996.

D'Agostino, V., Cesca, M., and Marchi, L.: Field and laboratory investigations of runout distances of debris flows in the Dolomites (Eastern Italian Alps), Geomorphology, 115, 294-304, 2010.

Dai, F. C., Xu, Q., Yao, X., Xu, L., Tu, X. B., and Gong, Q. M.: Spatial distribution of landslides triggered by the 2008 Ms 8.0 Wenchuan earthquake, China, J. Asian Earth Sci., 40, 833895, 2011.

Fannin, R. J. and Wise, M. P.: An empirical-statistical model for debris flow travel distance, Can. Geotech. J., 38, 982-994, 2001.

Gorum, T., Fan, X. M., Westen, C. J., Huang, R. Q., and Xu, Q.: Distribution pattern of earthquake-induced landslides triggered by the 12 May 2008 Wenchuan earthquake, Geomorphology, 133, 152-167, 2011.

Guo, D. P. and Hamada, M.: Qualitative and quantitative analysis on landslide influential factors during Wenchuan earthquake: a case study in Wenchuan County, Eng. Geol., 152, 202-209, 2013.

30 Hattanji, T. and Moriwaki, H.: Morphometric analysis of relic landslides using detailed landslide distribution maps: implications for forecasting travel distance of future landslides, Geomorphology, 103, 447-454, 2009.
NHESSD

2, 613-647, 2014

\section{Influential factors on landslide mobility \\ during the Wenchuan earthquake}

D. P. Guo et al.

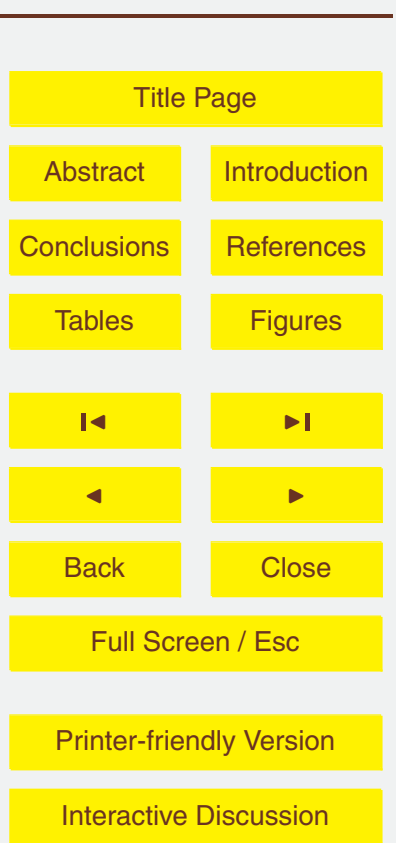


Hattanji, T. and Moriwaki, H.: Topographic features and mobility of old landslides in Tanzawa and Hakone areas - focusing on equivalent coefficient of dynamic friction and areal expansion of landslide mass, J. Jpn. Landslide Soc., 48, 45-51, 2011 (in Japanese with English abstract).

5 Heim, A.: Bergsturz und Menschenleben, Fretz und Wasmuth, Zurich, 218 pp., 1932.

Hsü, K. J.: Catastrophic debris streams (sturzstroms) generated by rock falls, Geol. Soc. Am. Bull., 86, 129-140, 1975.

Huang, R. Q. and Li, W. L.: Research on development and distribution rules of geohazards induced by Wenchuan earthquake on 12th May 2008, Chin. J. Rock Mechan. Eng., 27, 25852592, 2008 (in Chinese with English abstract).

Huang, R. Q. and Li, W. L.: Analysis on the number and density of landslides triggered by the 2008 Wenchuan earthquake, China, J. Geol. Hazard. Environ. Preserv., 20, 1-7, 2009a (in Chinese with English abstract).

Huang, R. Q. and Li, W. L.: Analysis of the geo-hazards triggered by the 12 May 2008 Wenchuan earthquake, China, B. Eng. Geol. Environ., 68, 363-371, 2009b.

Hungr, O.: A model for runout analysis of rapid flow slides, debris flows, and avalanches, Can. Geotech. J., 32, 610-623, 1995.

Hunter, G. and Fell, R.: Travel distance angle for "rapid" landslides in constructed and natural soil slopes, Can. Geotech. J., 40, 1123-1141, 2003.

20 Kokusho, T., Ishizawa, T., and Nishida, K.: Travel distance of failed slopes during 2004 Chuetsu earthquake and its evaluation in terms of energy, Soil Dyn. Earthq. Eng., 29, 1159-1169, 2009.

Lergros, F.: The mobility of long-runout landslides, Eng. Geol., 63, 301-331, 2002.

Okura, Y., Kitahara, H., Kawanami, and Sammori, T.: Fluidization in dry landslides, Eng. Geol., 56, 347-360, 2000a.

Okura, Y., Kitahara, H., Sammori, T., and Kawanami, A.: The effects of rockfall volume on runtout distance, Eng. Geol., 58, 109-124, $2000 \mathrm{~b}$.

Okura, Y., Kitahara, H., Kawanami, A., and Kurokawa, U.: Topography and volume effects on travel distance of surface failure, Eng. Geol., 67, 243-254, 2003.

30 Pudasaini, S. P. and Hutter, K.: Avalanche Dynamics: Dynamics of Rapid Flows of Dense Granular Avalanches, Springer, New York, 2007.

Pudasaini, S. P. and Miller, S. A.: The hypermobility of huge landslides and avalanches, Eng. Geol., 157, 124-132, 2013.

\section{NHESSD}

2, 613-647, 2014

\section{Influential factors on landslide mobility \\ during the Wenchuan earthquake}

D. P. Guo et al.

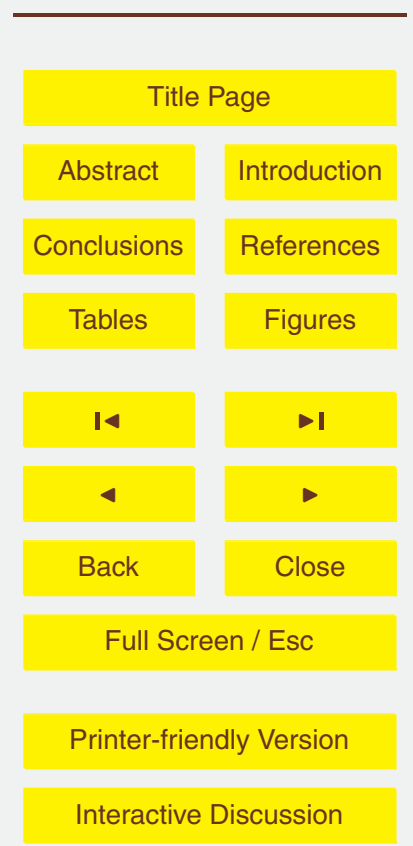


Qi, S. W., Xu, Q., Lan, H. X., Zhang, B., and Liu, J. Y.: Spatial distribution analysis of landslides triggered by 2008.5.12 Wenchuan earthquake, China, Eng. Geol., 116, 95-108, 2010.

Qi, S. W., Xu, Q., Zhang, B. Zhou, Y. D., Lan, H. X., and Li, L. H.: Source characteristics of long runout rock avalanches triggered by the 2008 Wenchuan earthquake, China, J. Asian Earth 5 Sci., 40, 896-906, 2011.

Shreve, R. L.: The Blackhawk Landslide, Geological Society of America, Special paper 108, 1-47, 1968.

Scheidegger, A. E.: On the prediction of the reach and velocity of catastrophic landslides, Rock Mech., 5, 231-236, 1973.

10 Tang, C., Zhu, J., Chang, M., Ding, J., and Qi, X.: An empirical-statistical model for predicting debris flow runtout zones in the Wenchuan earthquake area, Quatern. Int., 250, 63-73, 2012.

Xie, H. P., Deng, J. H., Tai, J. J., He, C. R., Wei, J. B., Chen, J. P., and Li, X. Y.: Wenchuan large earthquake and post-earthquake reconstruction-related geotechnical problems, Chin.

Xu, C., Dai, F. C., Yao, X., Chen, J., Tu, X. B., Sun, Y., and Wang, Z. Y.: GIS-based landslide susceptibility assessment using analytical hierarchy process in Wenchuan earthquake region, Chin. J. Rock Mechan. Eng.,, 28, Supp. 2, 1-8, 2009 (in Chinese with English abstract).

Xu, C., Dai, F. C., Yao, X., Chen, J., Tu, X. B., Cao, Y. B., and Xiao, J. Z.: GIS based certainty factor analysis of landslide triggering factors in Wenchuan earthquake, Chin. J. Rock Mechan. Eng., 29, Supp. 1, 2972-2981, 2010 (in Chinese with English abstract).

Xu, C., Xu, X. W., Wu, X. Y., Dai, F. C., Yao, X., and Yao, Q.: Detailed catalog of landslides triggered by the 2008 Wenchuan earthquake and statistical analyses of their spatial distribution, J. Eng. Geol., 21, 25-44, 2013a (in Chinese with English abstract).

Xu, C., Xu, X. W., Yao, X., and Dai, F. C.: Three (nearly) complete inventories of landslides triggered by the 12 May 2008 Wenchuan Mw 7.9 earthquake of China and their spatial distribution statistical analysis, Landslides, doi:10.1007/s10346-013-0404-6, 2013b.

Xu, Q., Pei, X. J., Huang, R. Q. et al.: Larger-scale landslides induced by the Wenchuan earthquake, Science Press, Beijing, 2009 (in Chinese).

so Yin, Y. P., Wang, F. W., and Sun, P.: Landslide hazards triggered by the 2008 Wenchuan earthquake, Sichuan, China, Landslides, 6, 139-151, 2009.

\section{NHESSD}

2, 613-647, 2014

\section{Influential factors on landslide mobility \\ during the Wenchuan earthquake}

D. P. Guo et al.

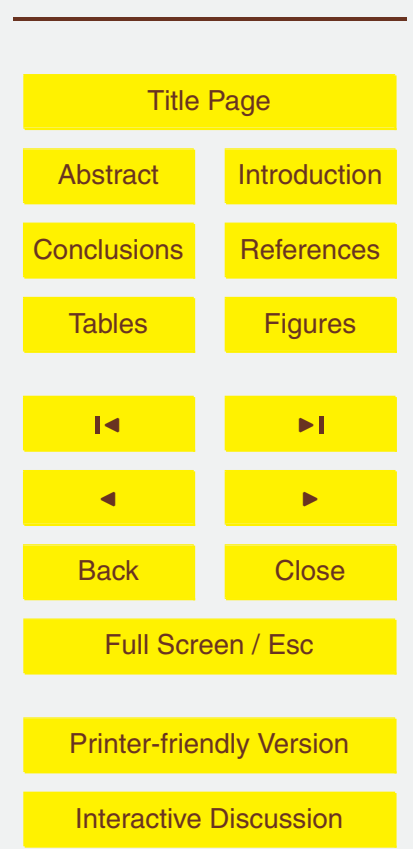




\section{NHESSD}

2, 613-647, 2014

\section{Influential factors on landslide mobility \\ during the Wenchuan earthquake \\ D. P. Guo et al.}

Table 1. Classification standard of rock type (Chang et al., 2006).

\begin{tabular}{|c|c|c|}
\hline Rock type & & Weathered degree and typical rock \\
\hline \multirow[t]{2}{*}{ Hard rock } & RT1 & $\begin{array}{l}\text { Non-weathered } \sim \text { slightly weathered magmatic rock, diorite, basalt, } \\
\text { andesite, gneiss and quartzite, etc. }\end{array}$ \\
\hline & RT2 & $\begin{array}{l}\text { (1) Non-weathered } \sim \text { slightly weathered marble, slate, limestone, } \\
\text { dolomite, metamorphic quartz rock, etc. } \\
\text { (2) Moderately weathered magmatic rock, diorite, basalt, andesite, } \\
\text { gneiss and quartzite, etc. }\end{array}$ \\
\hline \multirow[t]{2}{*}{ Soft rock } & RT3 & $\begin{array}{l}\text { (1) Non-weathered or slightly weathered tuff, phyllite, marl, sandy } \\
\text { mudstone, etc. } \\
\text { (2) Moderately strongly weathered hard rock }\end{array}$ \\
\hline & RT4 & $\begin{array}{l}\text { (1) Non-weathered } \sim \text { slightly weathered shale, mudstone, shaly } \\
\text { sand, etc. } \\
\text { (2) Strongly weathered hard rock } \\
\text { (3) Moderately } \sim \text { strongly weathered tuff, phyllite, marl, sandy mud- } \\
\text { stone, etc. }\end{array}$ \\
\hline
\end{tabular}

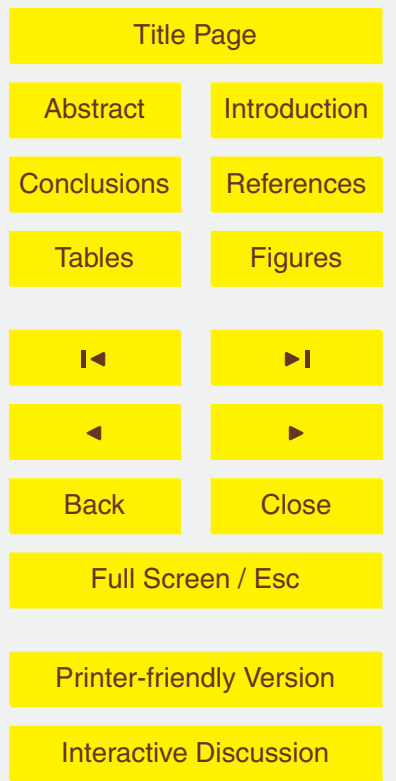




\section{NHESSD}

2, 613-647, 2014

\section{Influential factors on landslide mobility during the Wenchuan earthquake}

D. P. Guo et al.

Table 2. Regression parameters of seismic acceleration attenuations (Guo and Hamada, 2013).

\begin{tabular}{lccccc}
\hline $\begin{array}{l}\text { Hanging wall } \\
\text { or footwall }\end{array}$ & $a_{1}$ & $a_{2}$ & $a_{3}$ & $a_{4}$ & $R^{2}$ \\
\hline Hanging wall & -0.8203 & 13.767 & -0.0042 & 9.169 & 0.64 \\
Footwall & -0.6907 & 5.618 & -0.0072 & 7.939 & 0.55 \\
\hline
\end{tabular}

Title Page

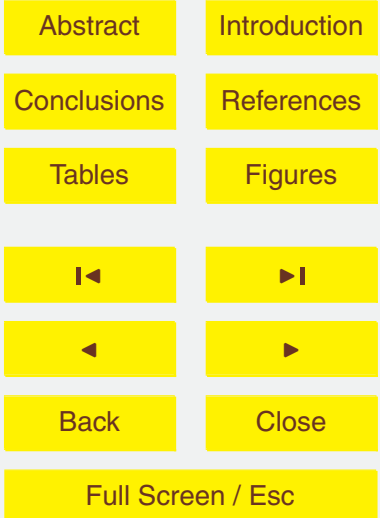

Printer-friendly Version

Interactive Discussion 
Table 3. Correlation coefficients among influential factors.

\begin{tabular}{lcccccc}
\hline & $\tan \theta$ & $\sin \beta$ & $\log h$ & $\log V$ & $\log \mathrm{PHA}$ & $\mathrm{RT}$ \\
\hline $\tan \theta$ & 1 & 0.386 & 0.232 & -0.067 & 0.161 & -0.190 \\
$\sin \beta$ & & 1 & 0.452 & 0.074 & 0.352 & -0.140 \\
$\log h$ & & & 1 & 0.545 & 0.037 & 0.016 \\
$\log V$ & & & & 1 & 0.158 & 0.026 \\
$\log \mathrm{PHA}$ & & & & & 1 & -0.072 \\
$\mathrm{RT}$ & & & & & & 1 \\
\hline
\end{tabular}

NHESSD

2, 613-647, 2014

Influential factors on landslide mobility during the Wenchuan earthquake

D. P. Guo et al.

Title Page

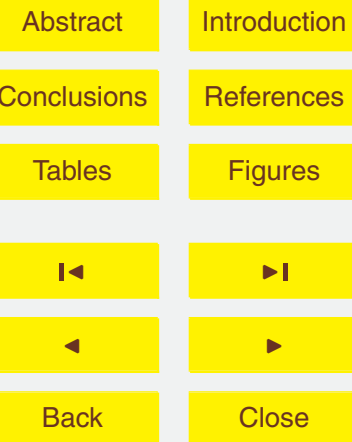

Full Screen / Esc

Printer-friendly Version

Interactive Discussion 


\section{NHESSD}

2, 613-647, 2014

\section{Influential factors on landslide mobility during the Wenchuan earthquake}

Table 4. Multivariable analysis of landslide mobility by backward elimination approach.

\begin{tabular}{|c|c|c|c|c|c|c|c|c|c|c|c|}
\hline \multicolumn{12}{|c|}{$\mu=H_{\max } / L_{\max }=b_{1} \log h+b_{2} \mathrm{RT}+b_{3} \sin \beta+b_{4} \log V+b_{5} \tan \theta+b_{6} \log \mathrm{PHA}$} \\
\hline $\begin{array}{r}\text { Variable } \\
\text { parame }\end{array}$ & & $b_{1}$ & $b_{2}$ & $b_{3}$ & $b_{4}$ & $b_{5}$ & $b_{6}$ & $\begin{array}{c}\text { Multiple } \\
\quad R\end{array}$ & $\begin{array}{c}\text { Adjusted } \\
R^{2}\end{array}$ & $\begin{array}{l}F \text {-stat } \\
\left(F_{0.05}\right)\end{array}$ & $\begin{array}{l}t \text { test } \\
\left(t_{0.05}\right)\end{array}$ \\
\hline 6 variables & $\begin{array}{c}b_{i} \\
t \text {-stat } \\
b_{i}^{\prime}\end{array}$ & $\begin{array}{l}0.505 \\
4.248 \\
0.513\end{array}$ & $\begin{array}{l}-0.073 \\
-3.259 \\
-0.412\end{array}$ & $\begin{array}{l}-0.412 \\
-2.851 \\
-0.414\end{array}$ & $\begin{array}{l}-0.086 \\
-2.086 \\
-0.335\end{array}$ & $\begin{array}{l}0.124 \\
1.237 \\
0.171\end{array}$ & $\begin{array}{l}-0.015 \\
-0.098 \\
-0.012\end{array}$ & 0.972 & 0.914 & $115.774(2.342)$ & 2.023 \\
\hline 5 variables & $\begin{array}{c}b_{i} \\
t \text {-stat } \\
b_{i}^{\prime}\end{array}$ & $\begin{array}{l}0.504 \\
4.307 \\
0.512\end{array}$ & $\begin{array}{l}-0.073 \\
-3.309 \\
-0.413\end{array}$ & $\begin{array}{l}-0.415 \\
-2.998 \\
-0.418\end{array}$ & $\begin{array}{l}-0.087 \\
-2.244 \\
-0.340\end{array}$ & $\begin{array}{l}0.122 \\
1.252 \\
0.169\end{array}$ & & 0.972 & 0.916 & $142.365(2.449)$ & 2.021 \\
\hline 4 variables & $\begin{array}{c}b_{i} \\
t \text {-stat } \\
b_{i}^{\prime}\end{array}$ & $\begin{array}{l}0.564 \\
5.247 \\
0.573\end{array}$ & $\begin{array}{l}-0.077 \\
-3.512 \\
-0.436\end{array}$ & $\begin{array}{l}-0.376 \\
-2.768 \\
-0.378\end{array}$ & $\begin{array}{l}-0.096 \\
-2.477 \\
-0.372\end{array}$ & & & 0.971 & 0.916 & $175.196(2.600)$ & 2.020 \\
\hline
\end{tabular}

D. P. Guo et al.

Title Page

\begin{tabular}{|c|c|}
\hline Abstract & Introduction \\
\hline Conclusions & References \\
\hline Tables & Figures \\
\hline $\mathbf{1}$ & \\
\hline & \\
\hline Back & Close \\
\hline Full Screen / Esc \\
\hline
\end{tabular}

Printer-friendly Version

Interactive Discussion 


\section{NHESSD}

2, 613-647, 2014

\section{Influential factors on landslide mobility during the Wenchuan earthquake}

Table 5. Landslide mobility prediction models and their comparisons.

\begin{tabular}{lclc}
\hline Prediction models & Data source & Authors & Average error \\
\hline$\mu=0.564 \log h-0.077 \mathrm{RT}-0.376 \sin \beta-0.096 \log V$ & 46 landslides & This paper & $21.16 \%$ \\
$\log \mu=-0.157 \log V+0.624$ & 33 landslides & Scheidegger (1973) & $31.11 \%$ \\
$\mu=0.16 V^{-0.15}$ & 32 landslides & Legros (2000) & $31.22 \%$ \\
$\log \mu=-0.085 \log V-0.047$ & 204 landslides & Corominas (1996) & $43.73 \%$ \\
$\mu=0.69 \tan \theta+0.086$ & (including 71 debris flows) & Hunter and Fell (2003) & $45.97 \%$ \\
\hline
\end{tabular}

Hint: $V$ in unit of $\mathrm{m}^{3}$ except the model of Legros (2000), in which $V$ is in unit of $\mathrm{km}^{3}$.

D. P. Guo et al.

Title Page

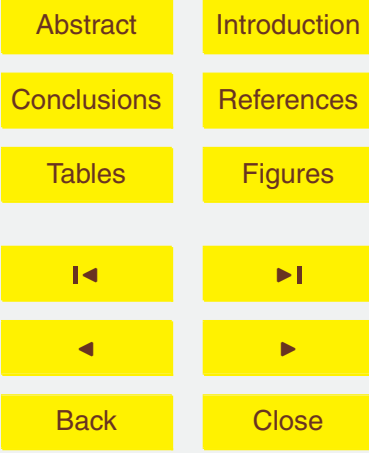

Full Screen / Esc

Printer-friendly Version

Interactive Discussion 


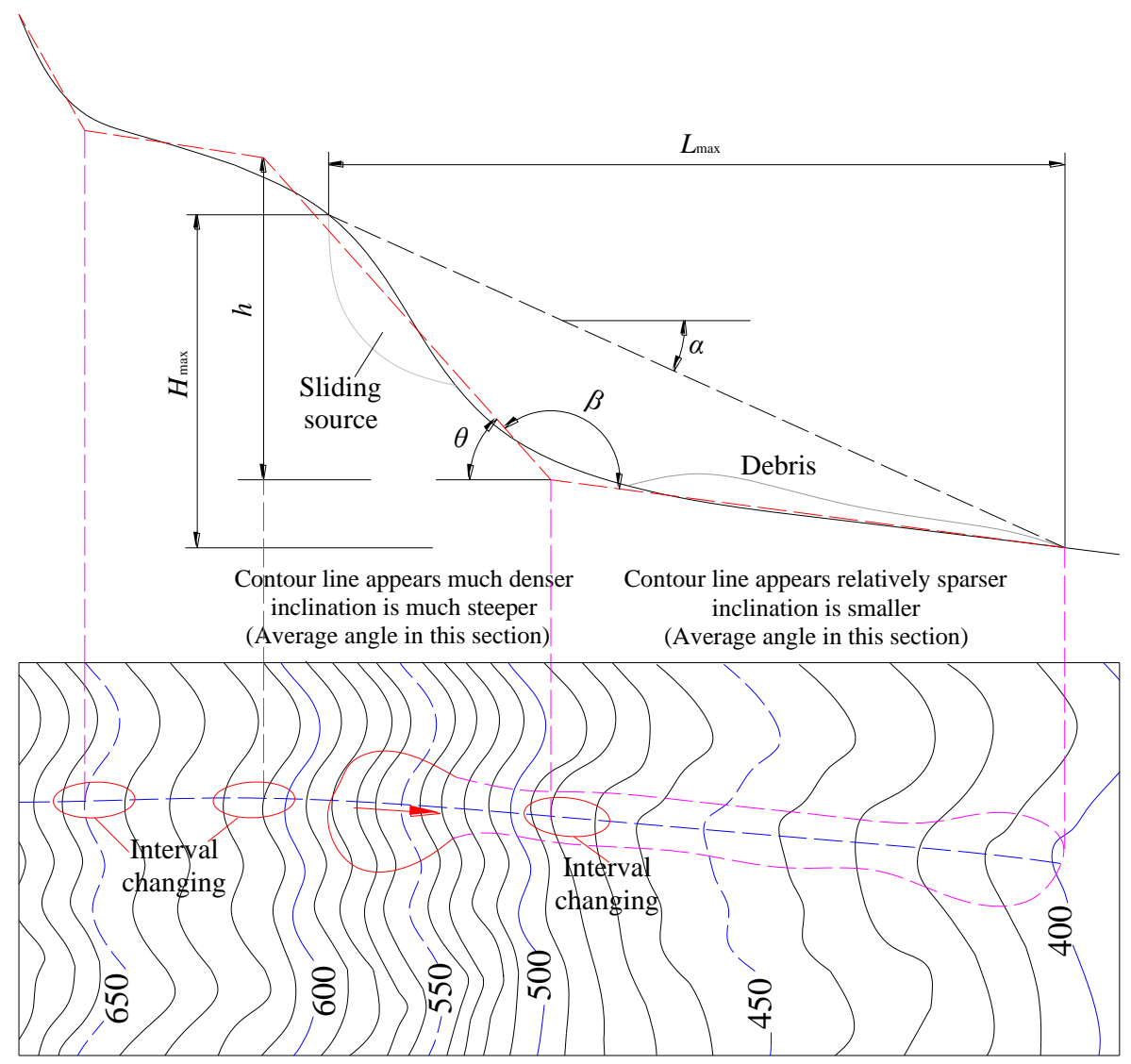

\section{NHESSD}

2, 613-647, 2014

\section{Influential factors on landslide mobility during the Wenchuan earthquake}

D. P. Guo et al.

Title Page

\begin{tabular}{|c|c|}
\hline Abstract & Introduction \\
\hline Conclusions & References \\
\hline Tables & Figures \\
\hline $\mathbf{1}$ & \\
\hline & \\
\hline Back & Close \\
\hline Full Screen / Esc \\
\hline
\end{tabular}

Fig. 1. The sketch of landslide and its deposit for terminological definitions.

Printer-friendly Version

Interactive Discussion 


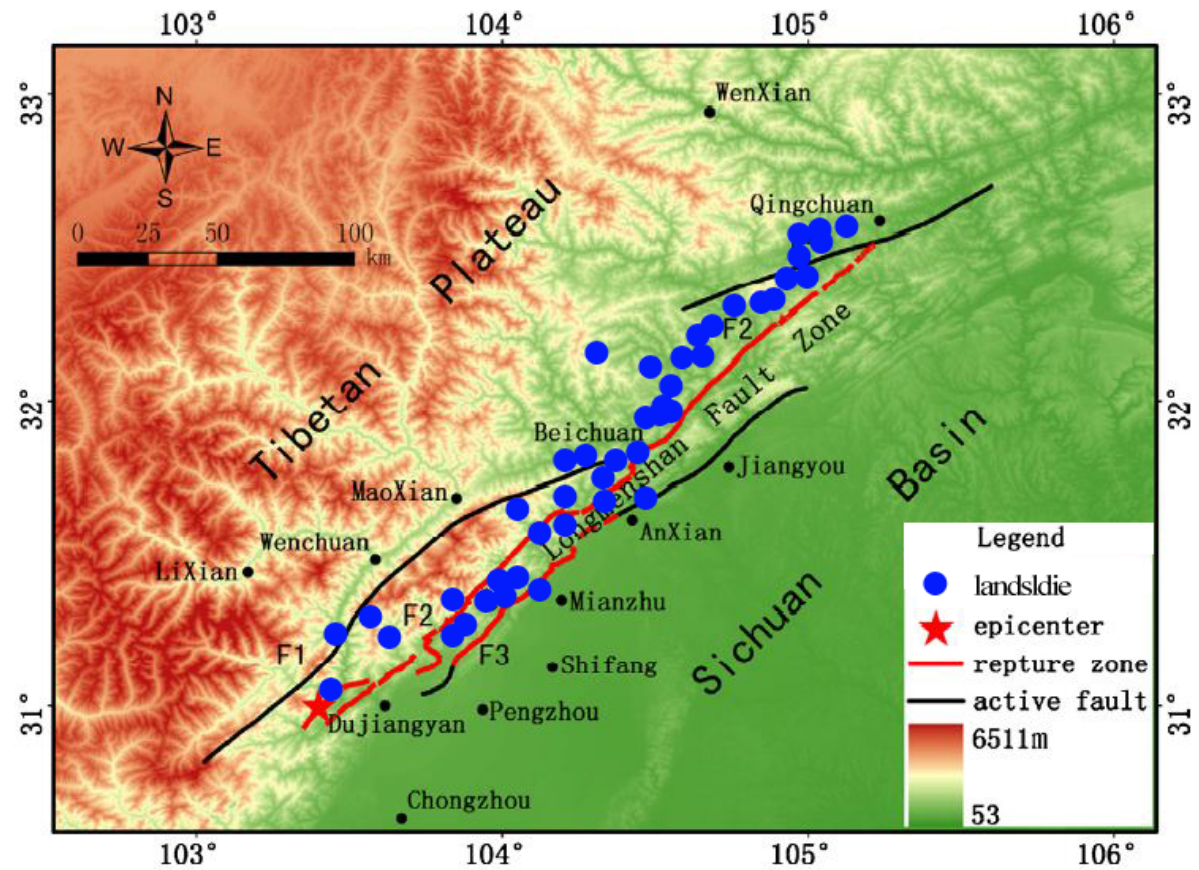

Fig. 2. The location of 46 landslides; F1 represents Wenchuan-Maoxian fault, F2 represents Yingxiu-Beichuan fault, F3 represents Guanxian-Anxian fault (based on Qi. et al., 2011).

\section{NHESSD}

2, 613-647, 2014

\section{Influential factors on landslide mobility during the Wenchuan earthquake}

D. P. Guo et al.

\begin{tabular}{|c|c|}
\hline \multicolumn{2}{|c|}{ Title Page } \\
\hline Abstract & Introduction \\
\hline Conclusions & References \\
\hline Tables & Figures \\
\hline I4 & \\
\hline & \\
\hline Back & \\
\hline Full Screen / Esc \\
\hline
\end{tabular}




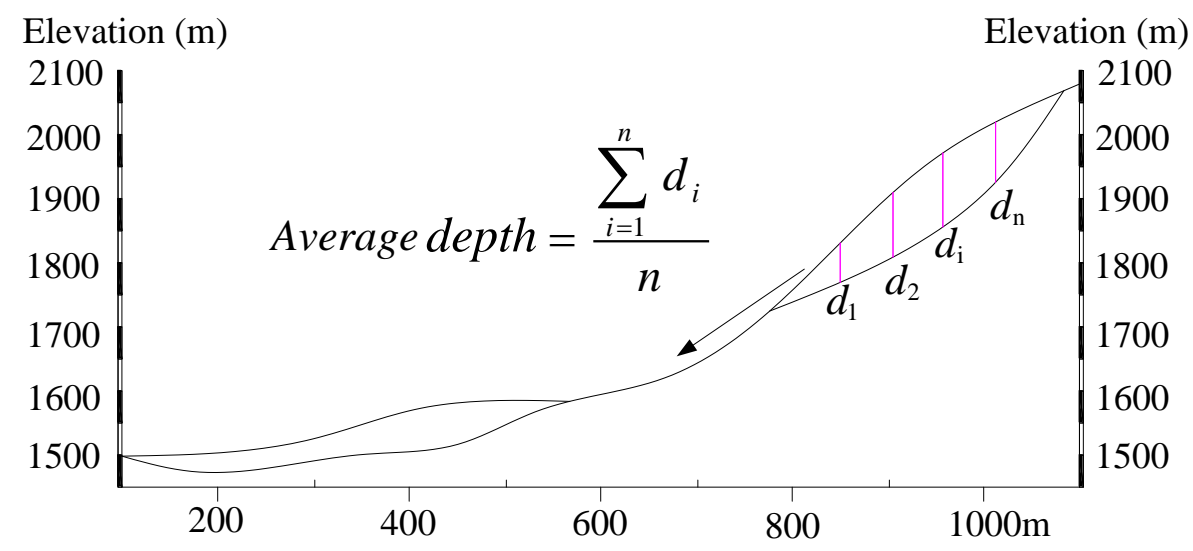

Fig. 3. Typical longitudinal profile of a landslide.

\section{NHESSD}

2, 613-647, 2014

\section{Influential factors on landslide mobility during the Wenchuan earthquake \\ D. P. Guo et al.}

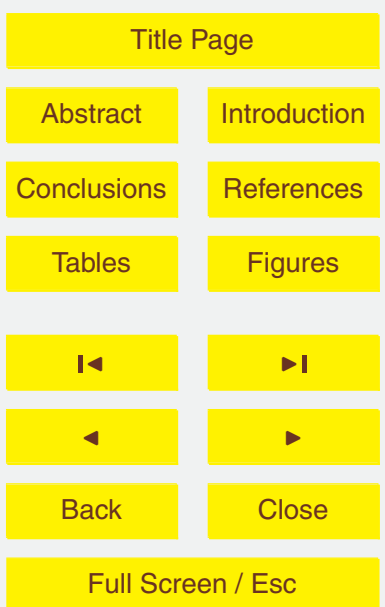

Printer-friendly Version

Interactive Discussion 


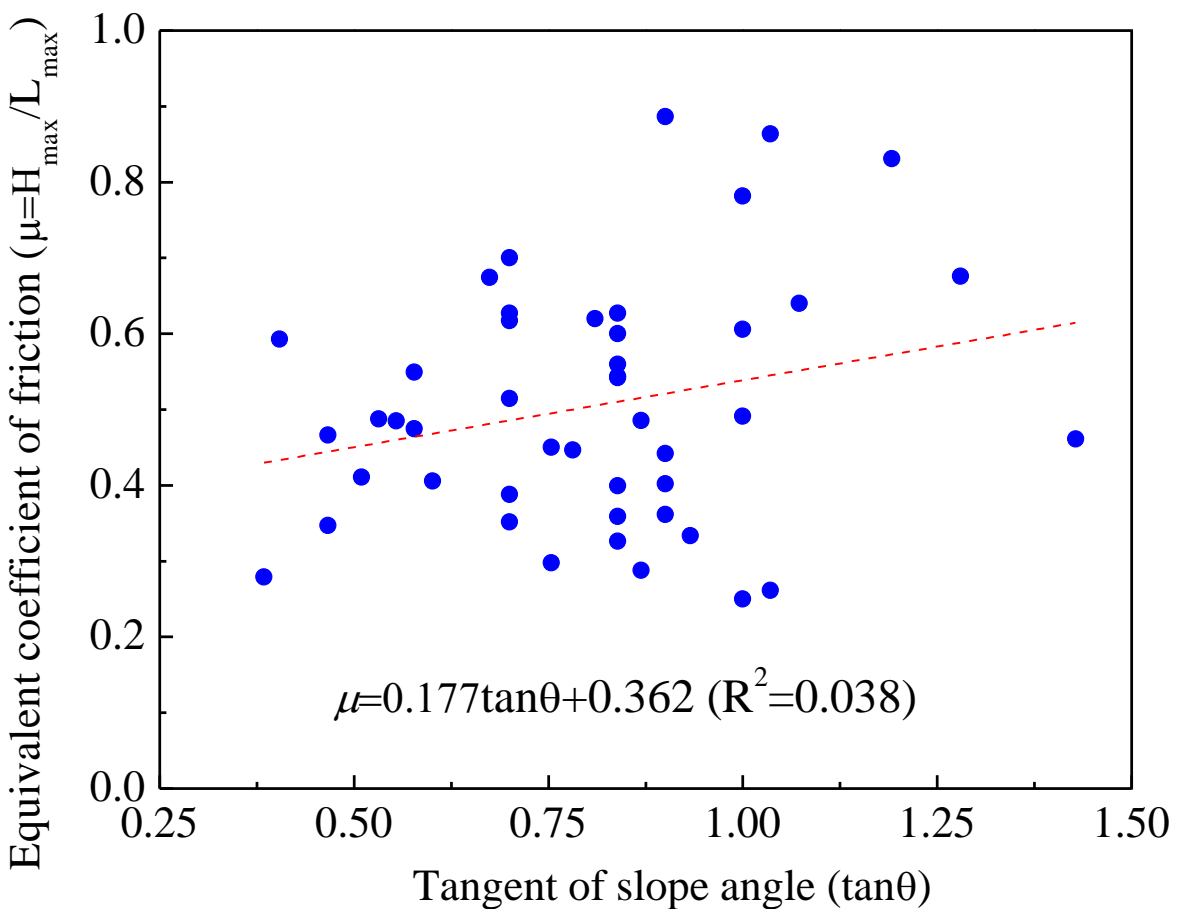

Influential factors on landslide mobility during the Wenchuan earthquake

D. P. Guo et al.

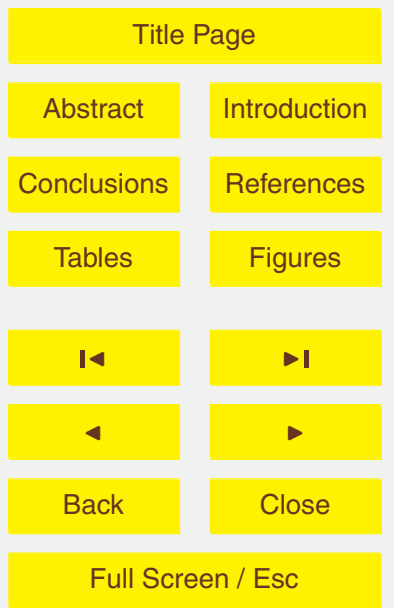

Printer-friendly Version

Interactive Discussion 


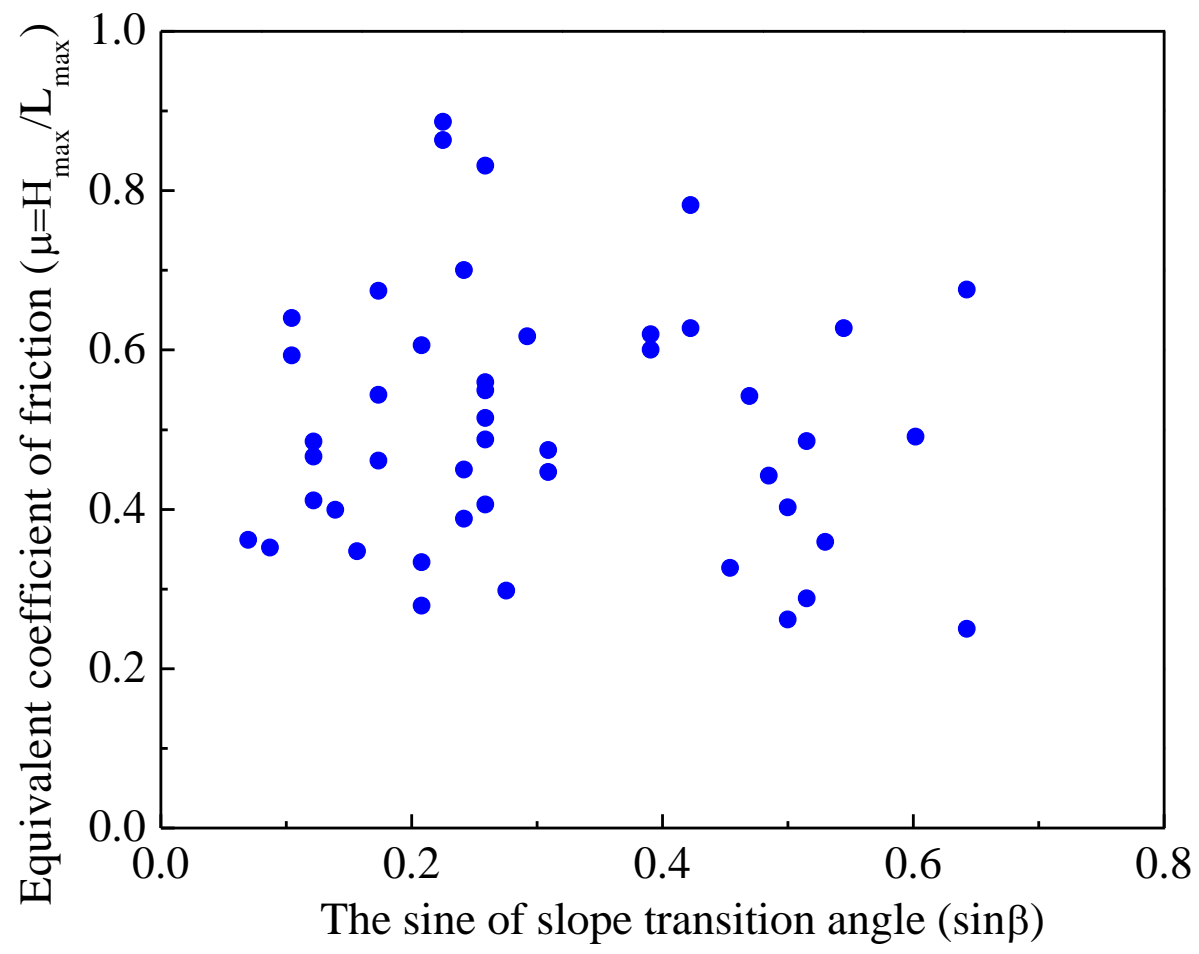

Fig. 5. Equivalent coefficient of friction related to the sine of slope transition angle.

\section{NHESSD}

2, 613-647, 2014

Influential factors on landslide mobility during the Wenchuan earthquake

D. P. Guo et al.

Title Page

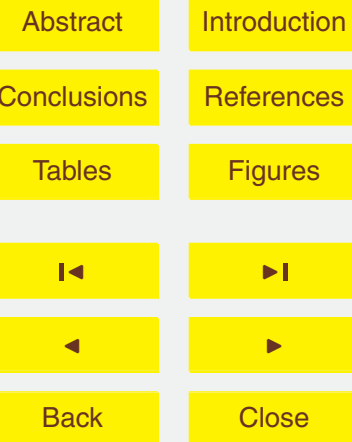

Full Screen / Esc

Printer-friendly Version

Interactive Discussion 


\section{NHESSD}

2, 613-647, 2014

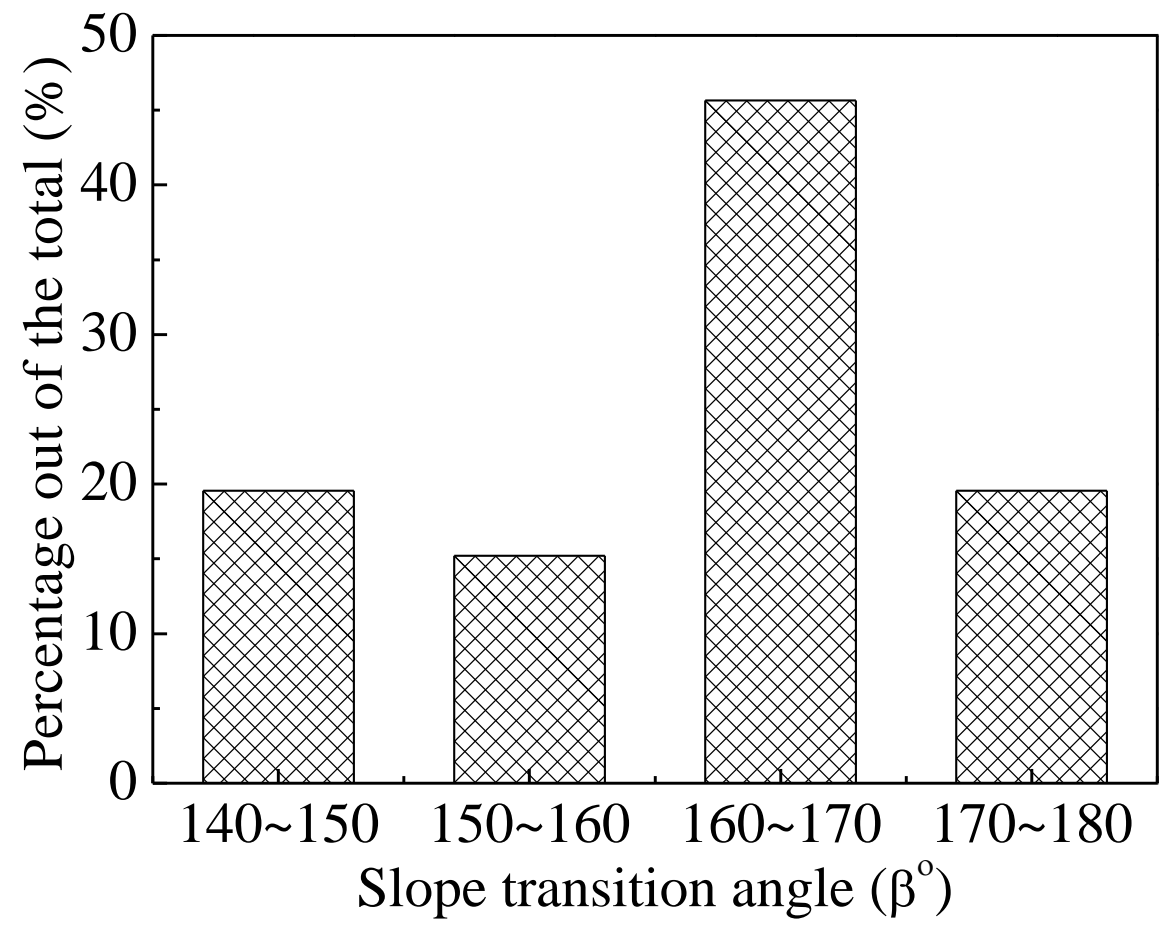

Influential factors on landslide mobility during the Wenchuan earthquake

D. P. Guo et al.

Title Page

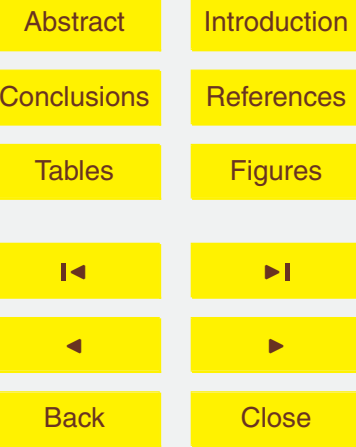

Full Screen / Esc

Fig. 6. Statistical histogram of slope transition angle.

Printer-friendly Version

Interactive Discussion 


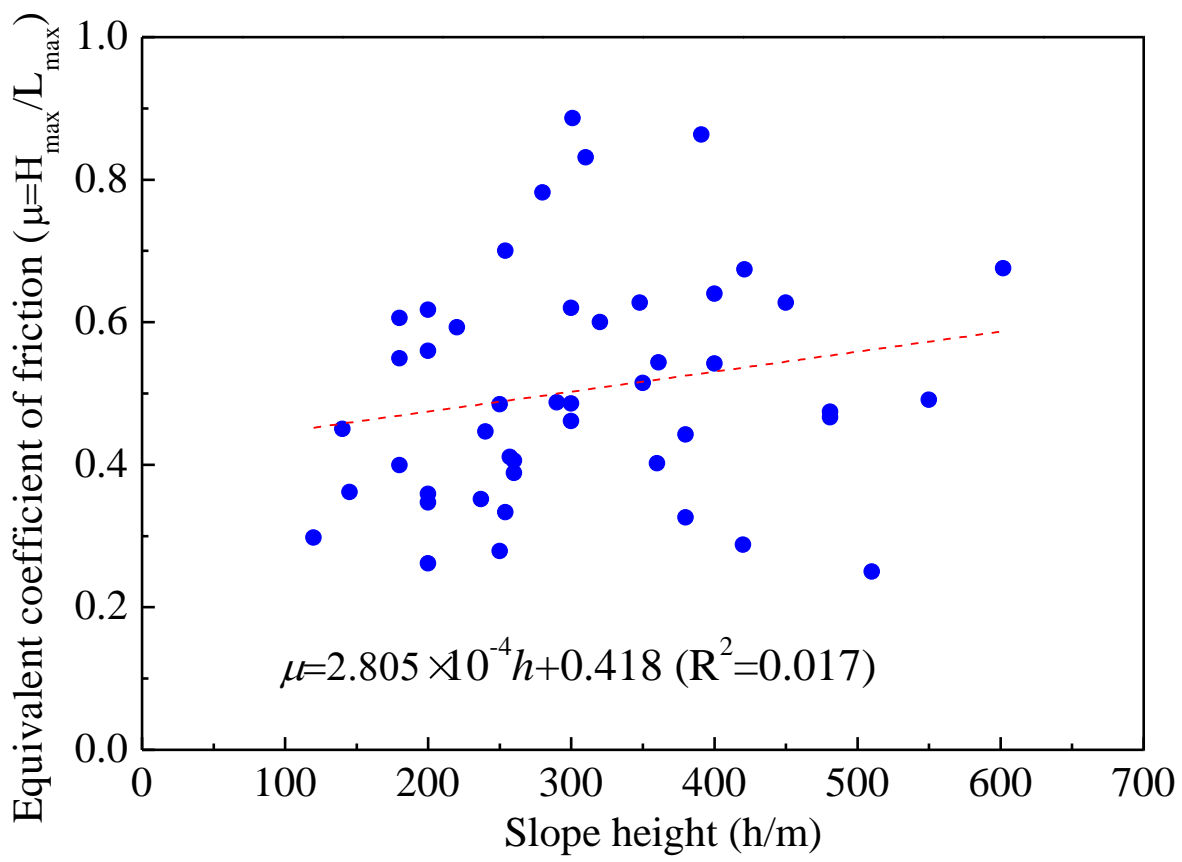

\section{Influential factors on landslide mobility during the Wenchuan earthquake \\ D. P. Guo et al.}

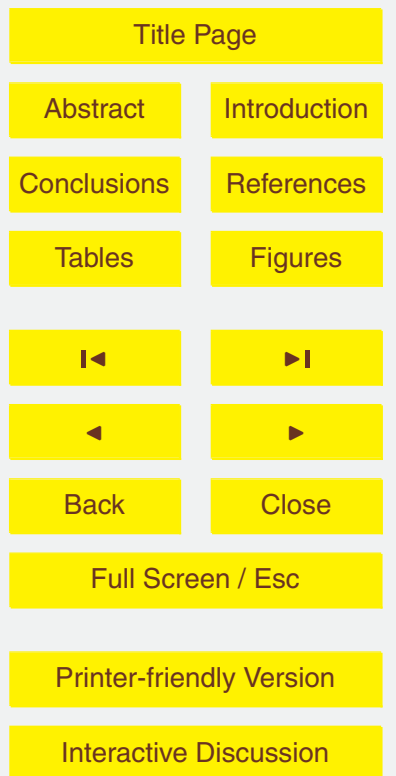




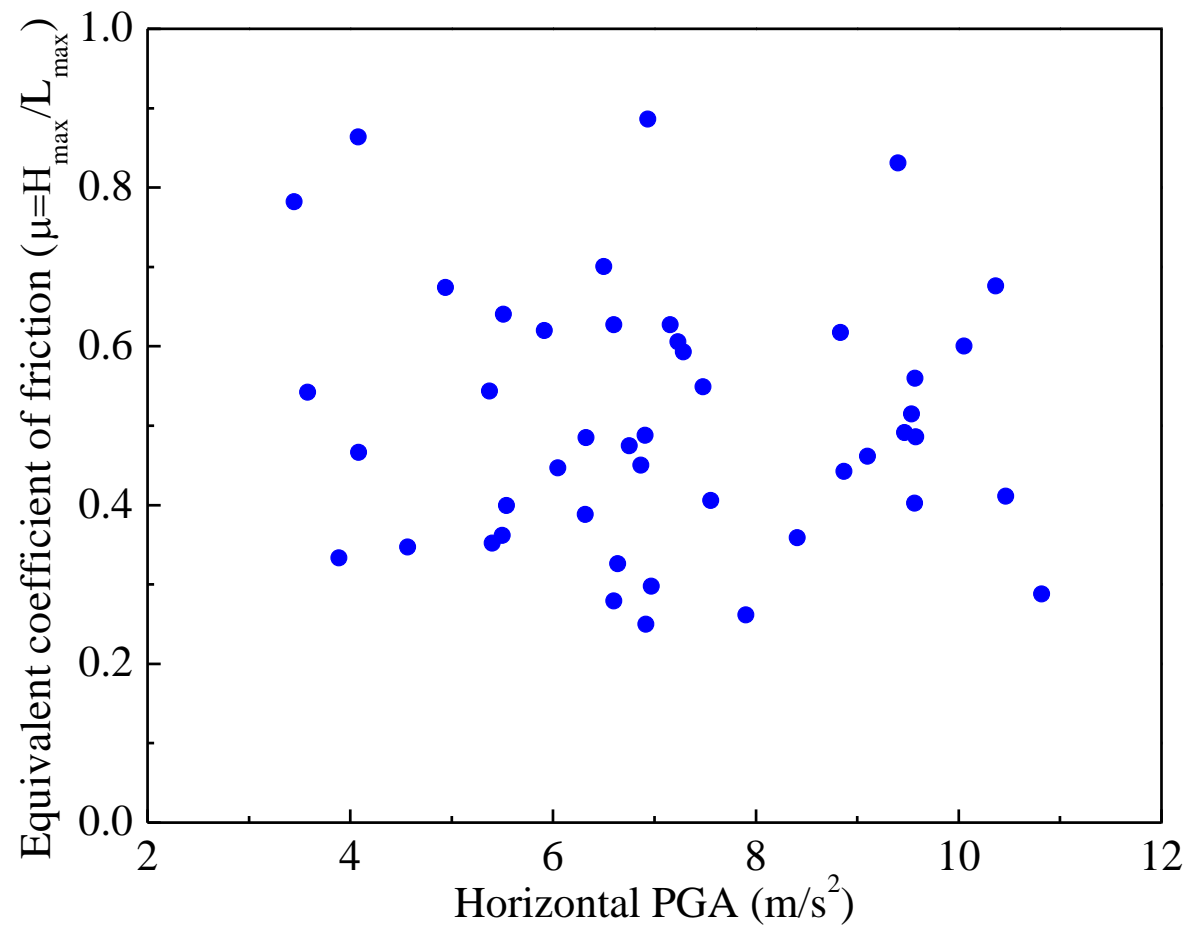

\section{NHESSD}

2, 613-647, 2014

Influential factors on landslide mobility during the Wenchuan earthquake

D. P. Guo et al.

Title Page

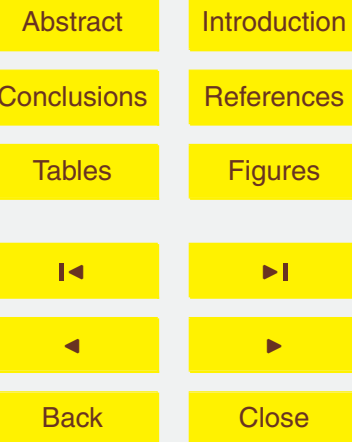

Full Screen / Esc

Fig. 8. Equivalent coefficient of friction related to seismic acceleration.

Printer-friendly Version

Interactive Discussion 


\section{NHESSD}

2, 613-647, 2014

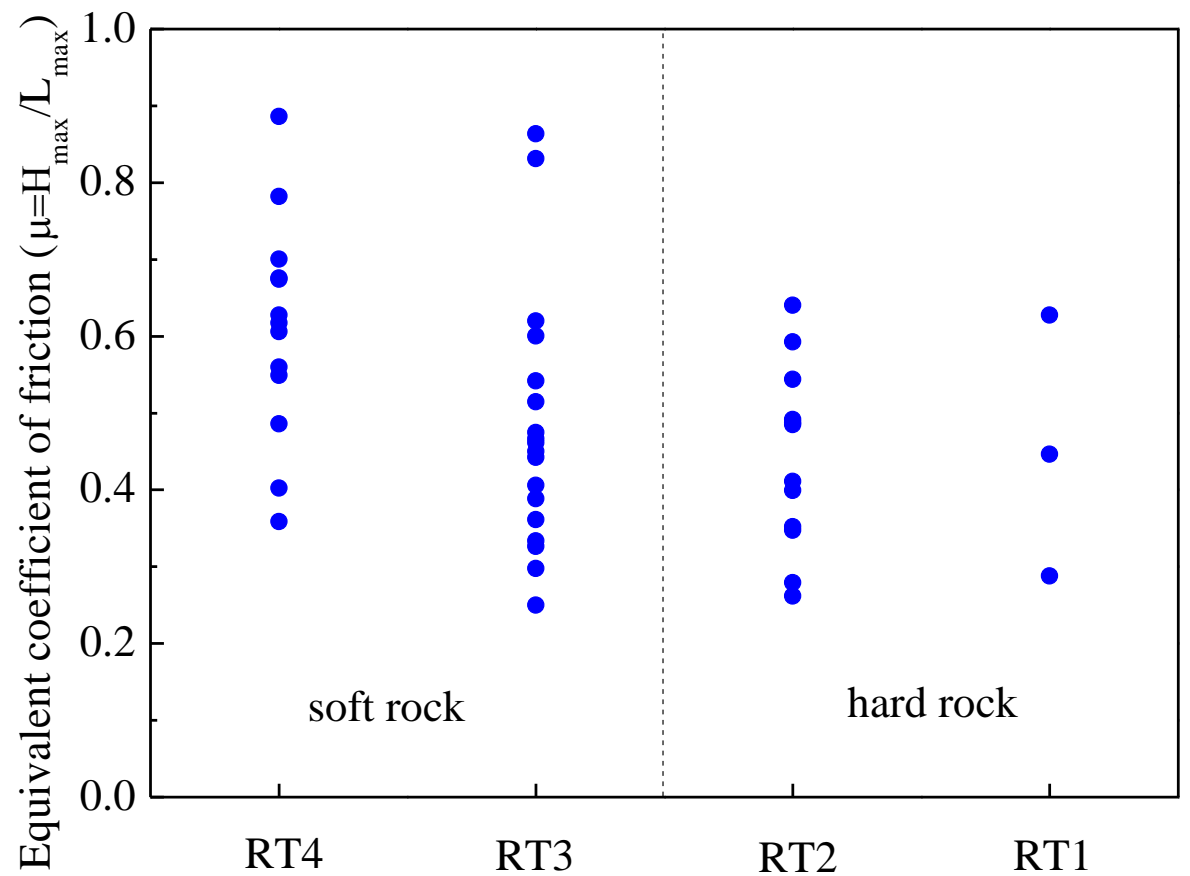

Influential factors on landslide mobility during the Wenchuan earthquake

D. P. Guo et al.

Title Page

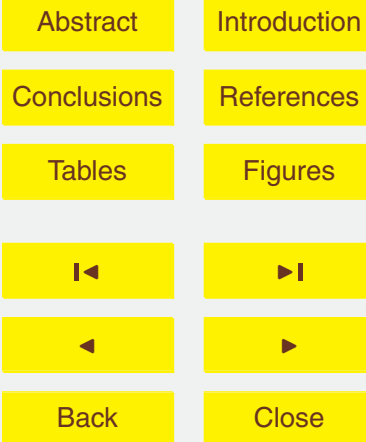

Full Screen / Esc

Printer-friendly Version

Interactive Discussion 


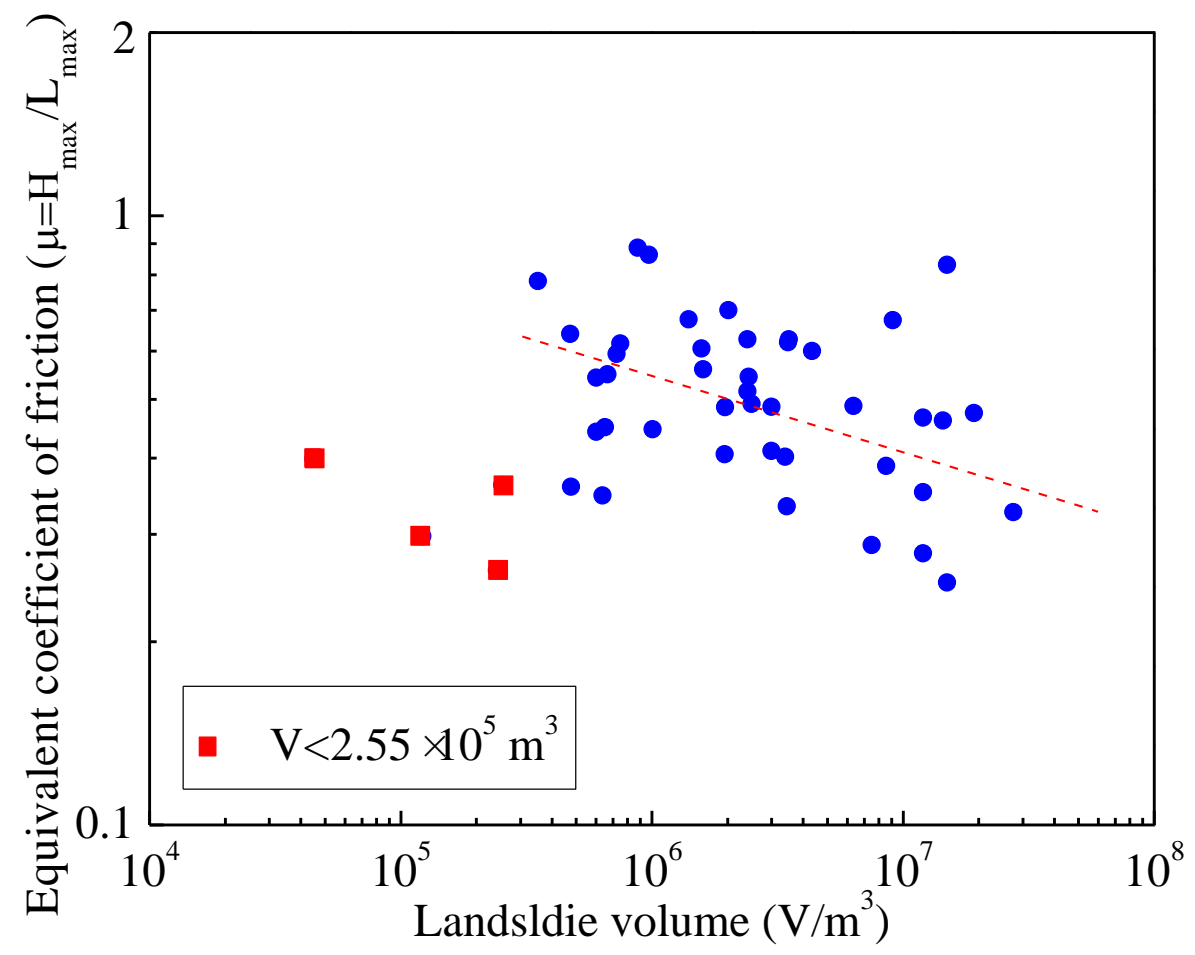

\section{Influential factors on landslide mobility during the Wenchuan earthquake \\ D. P. Guo et al.}

\section{Title Page}

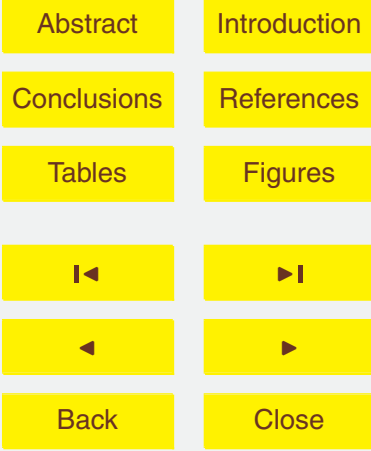

Full Screen / Esc

Fig. 10. Equivalent coefficient of friction related to landslide source volume.

Printer-friendly Version

Interactive Discussion 


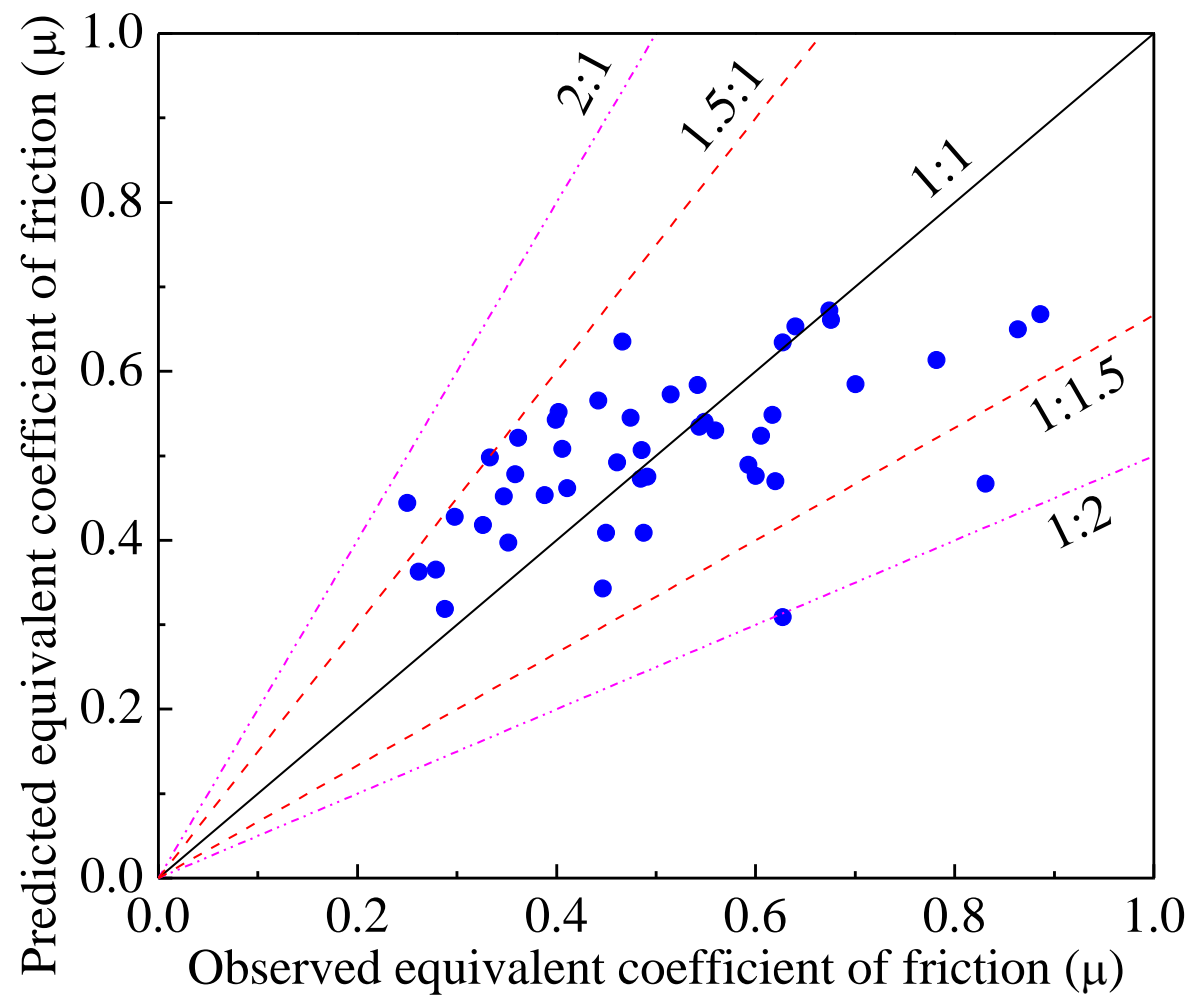

\section{NHESSD}

2, 613-647, 2014

Influential factors on landslide mobility during the Wenchuan earthquake

D. P. Guo et al.

Title Page

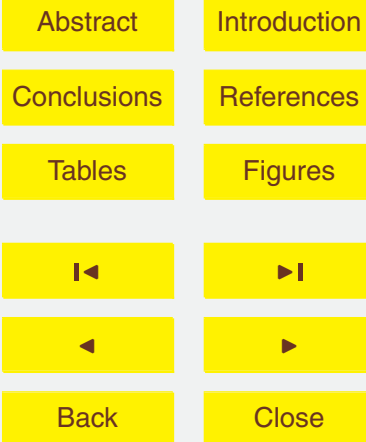

Full Screen / Esc

Fig. 11. Predicted vs. observed equivalent coefficent of friciton.

Printer-friendly Version

Interactive Discussion 

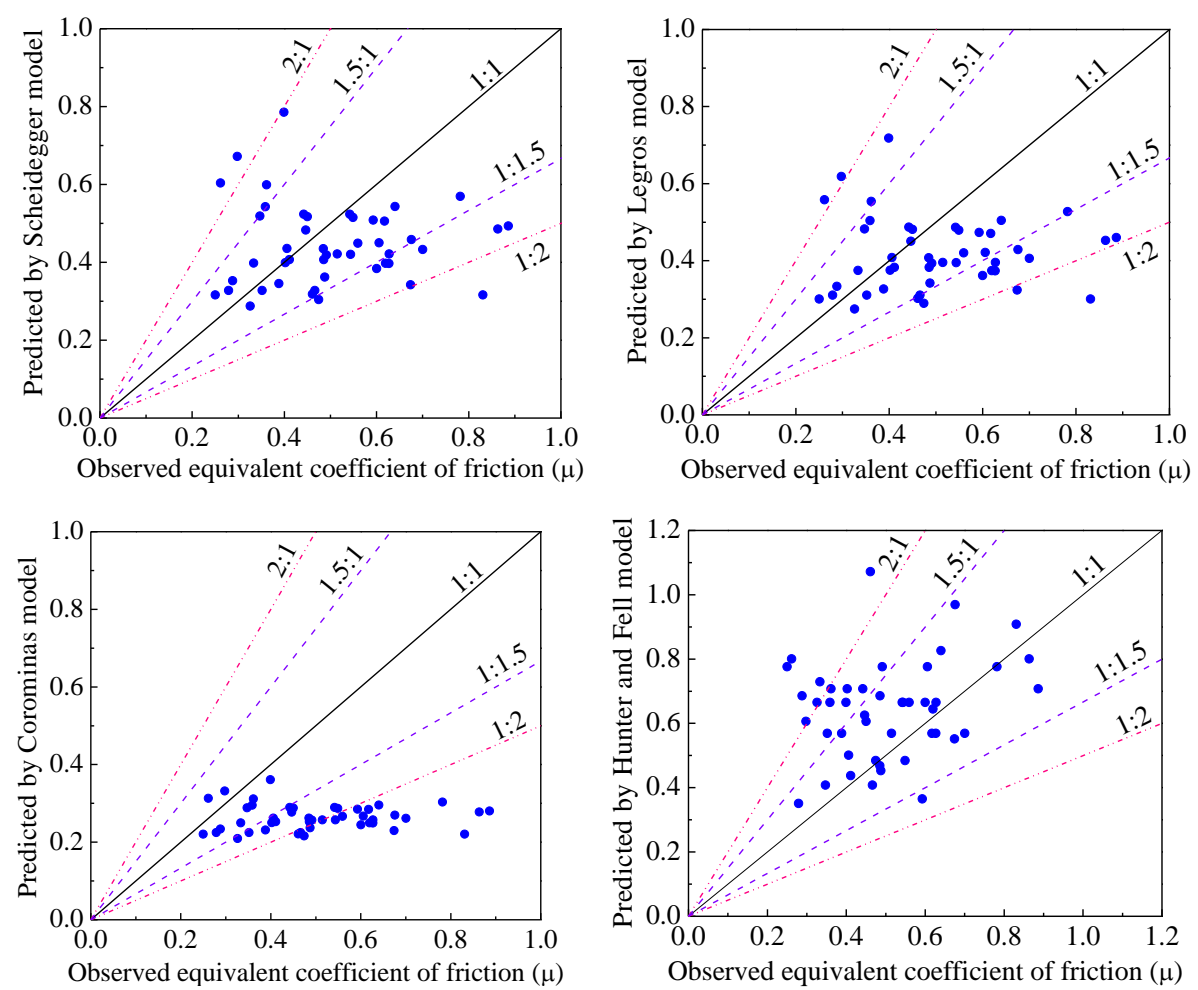

Fig. 12. Predicted equivalent coefficent of friciton by previous models vs. the observed.

\section{NHESSD}

2, 613-647, 2014

Influential factors on landslide mobility during the Wenchuan earthquake

D. P. Guo et al.

Title Page

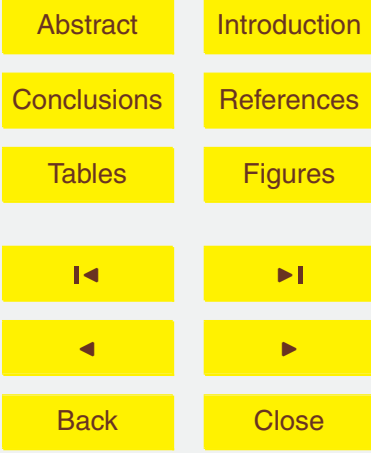

Full Screen / Esc

Printer-friendly Version

Interactive Discussion 